\title{
Poleward Shift of the Kuroshio Extension Front and Its Impact on the North Pacific Subtropical Mode Water in the Recent Decades
}

\author{
BAOLAN WU, ${ }^{\text {a,b,c }}$ XIAOPEI LIN, ${ }^{\text {a,b }}$ AND LISAN Yu ${ }^{c}$ \\ ${ }^{\text {a }}$ Frontier Science Center for Deep Ocean Multispheres and Earth System and Physical Oceanography Laboratory, \\ Ocean University of China, Qingdao, China \\ ${ }^{\mathrm{b}}$ Qingdao National Laboratory for Marine Science and Technology, Qingdao, China \\ ${ }^{\mathrm{c}}$ Department of Physical Oceanography, Woods Hole Oceanographic Institution, Woods Hole, Massachusetts
}

(Manuscript received 26 April 2020, in final form 17 November 2020)

\begin{abstract}
The meridional shift of the Kuroshio Extension (KE) front and changes in the formation of the North Pacific Subtropical Mode Water (STMW) during 1979-2018 are reported. The surface-to-subsurface structure of the KE front averaged over $142^{\circ}-165^{\circ} \mathrm{E}$ has shifted poleward at a rate of $\sim 0.23^{\circ} \pm 0.16^{\circ}$ decade $^{-1}$. The shift was caused mainly by the poleward shift of the downstream KE front $\left(153^{\circ}-165^{\circ} \mathrm{E}, \sim 0.41^{\circ} \pm 0.29^{\circ}\right.$ decade $\left.^{-1}\right)$ and barely by the upstream KE front $\left(142^{\circ}-153^{\circ} \mathrm{E}\right)$. The long-term shift trend of the KE front showed two distinct behaviors before and after 2002. Before 2002, the surface KE front moved northward with a faster rate than the subsurface. After 2002, the surface KE front showed no obvious trend, but the subsurface KE front continued to move northward. The ventilation zone of the STMW, defined by the area between the $16^{\circ}$ and $18^{\circ} \mathrm{C}$ isotherms or between the 25 and $25.5 \mathrm{~kg} \mathrm{~m}^{-3}$ isopycnals, contracted and displaced northward with a shoaling of the mixed layer depth $h_{m}$ before 2002 when the KE front moved northward. The STMW subduction rate was reduced by $0.76 \mathrm{~Sv}\left(63 \% ; 1 \mathrm{~Sv} \equiv=10^{6} \mathrm{~m}^{3} \mathrm{~s}^{-1}\right)$ during 1979-2018, most of which occurred before 2002. Of the three components affecting the total subduction rate, the temporal induction $\left(-\partial h_{m} / \partial t\right)$ was dominant accounting for $91 \%$ of the rate reduction, while the vertical pumping $\left(-w_{\mathrm{mb}}\right)$ amounted to $8 \%$ and the lateral induction $\left(-\mathbf{u}_{\mathrm{mb}} \cdot \nabla h_{m}\right)$ was insignificant. The reduced temporal induction was attributed to both the contracted ventilation zone and the shallowed $h_{m}$ that were incurred by the poleward shift of KE front.
\end{abstract}

KEYWORDS: Boundary currents; Decadal variability; Fronts; Water masses/storage

\section{Introduction}

The Kuroshio is a strong western boundary current of the wind-driven subtropical gyre in the North Pacific Ocean. It generally separates from Japan at Cape Inubo around $35^{\circ} \mathrm{N}$, and flows eastward as the Kuroshio Extension (KE) in the form of a narrow jet (Fig. 1). The front associated with the KE, called the KE front, is deep, featuring a strong subsurface temperature gradient but a modest sea surface temperature (SST) gradient (Nonaka et al. 2006). The KE front is strongest near the Japan coast about $143^{\circ} \mathrm{E}$, and strengthens in winter and weakens in summer (Chen 2008). In the south of the KE front, the North Pacific Subtropical Mode Water (STMW; dashed contours in Fig. 1) is formed in winter and is then subducted into the thermocline and advected by the mean circulation (Masuzawa 1969; Hanawa 1987). The STMW lies between the seasonal and main thermoclines and is characterized as a thermostad of $16^{\circ}-18^{\circ} \mathrm{C}$, or a potential vorticity minimum (vertically homogeneous) zone (Masuzawa 1969; Hanawa 1987). The STMW transports mass, heat, and nutrients from the surface into the subsurface ocean and is thought to carry memory of climate variability, as some of the waters reemerge in the next winter and contribute to the observed winter-towinter persistence of SST anomalies (e.g., Alexander et al. 1999; Sugimoto and Hanawa 2005). It is believed that the STMW variation has an important influence on midlatitude

Corresponding author: Xiaopei Lin, linxiaop@ouc.edu.cn climate variability (e.g., Oka and Qiu 2012) and oceanic uptake of atmospheric $\mathrm{CO}_{2}$ (Bates et al. 2002), and can regulate biogeochemical process via the nutrient cycling in the oligotrophic subtropical gyres (e.g., Oka et al. 2015).

Studies have shown that the state of the KE front modulates the formation of the STMW through its effect on the mixed layer depth (hereafter $h_{m}$; Qiu and Chen 2006). On the interannual to decadal time scales, a southerly (northerly) positioned KE front is associated with a weakened (strengthened) recirculation gyre and is often unstable (stable) with high (low) regional eddy activities. This high eddy activity induces high potential vorticity water (Sasaki and Minobe 2015), increasing subsurface ocean stratification that in turn inhibits the development of deep $h_{m}$ in winter (Sugimoto and Hanawa 2010) and the formation of the STMW (e.g., Oka et al. 2012; Cerovečki and Giglio 2016). However, the long-term relationship between the state of the KE front and the STMW formation remains less examined due to the lack of observations with sufficient temporal and spatial resolutions.

The state of the KE front is primarily determined by the large-scale wind field, e.g., the westerly winds over high latitudes associated with the easterly winds over low latitudes in the North Pacific Ocean (Sverdrup 1947; Stommel 1948; Munk 1950). Some studies suggested that the observed changes in the North Pacific wind field reflect the change of the Hadley cell (HC; e.g., Hudson et al. 2006; Seidel et al. 2008), which is a planetary-scale circulation spanning one-third of Earth from the tropics to the subtropics. The NOAA OISSTv2, September descending branch of the $\mathrm{HC}$ in the Northern Hemisphere is 


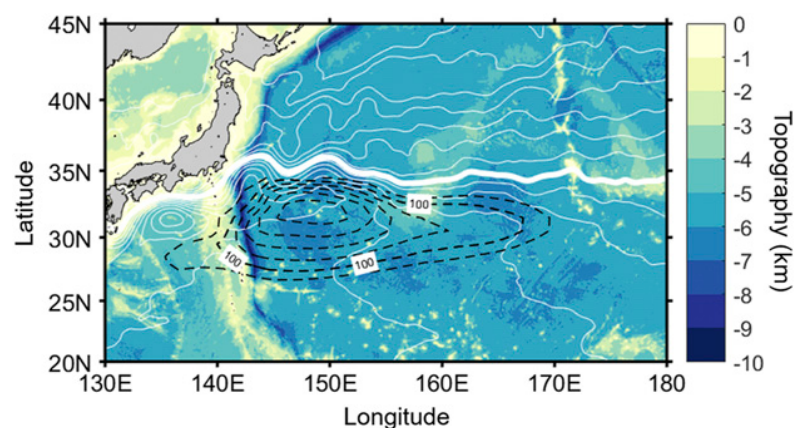

FIG. 1. The spatial relationship between the KE front position and the STMW thickness. The thick white line indicates the KE front position, which is defined as the $110-\mathrm{cm}$ SSH contour (see section 2a). Black dashed contours display the climatological thickness of the STMW (m) during 1979-2018. Color shading denotes the ocean bottom topography $(\mathrm{km})$, and white contours represent the SSH derived from AVISO, with an interval of $10 \mathrm{~cm}$.

located around $30^{\circ} \mathrm{N}$, where the KE front is located and the STMW forms. The aforementioned interannual to decadal variability of the state of the KE front is believed to be caused by the change of the wind stress curl (WSC) in the central Pacific induced by the Pacific decadal oscillation (PDO). When the PDO index is positive, the zero WSC line moves northward and the HC expands poleward (Qiu et al. 2014). Subsequently, negative sea surface height (SSH) and permanent pycnocline depth anomalies are generated in the central North Pacific and propagate westward at the speed of first-mode baroclinic Rossby waves. When the SST anomalies reach the KE front area after 3-4 years, they cause the KE front to become unstable and move southward.

The long-term relationship among the KE front movement, the STMW variability, and the large-scale wind changes is not yet clear. Multiple lines of evidence have indicated that the large-scale extratropical atmospheric circulation moves poleward under the global warming, characterized by the poleward movement of storm tracks (Yin 2005), westerly winds (Chen et al. 2008), jet streams (Archer and Caldeira 2008), and clouds (Norris et al. 2016). The poleward expanded HC (Lu et al. 2007) drives also the poleward shift of the subtropical gyres and western boundary currents (Wu et al. 2012; Yang et al. 2016, 2020a). A variety of metrics have been used to quantify the robust expansion of the $\mathrm{HC}$ since 1979 and several mechanisms (e.g., global warming, decadal variability, aerosol, etc.) have been proposed (e.g., Hudson et al. 2006; Seidel et al. 2008; Reichler 2009; Chen et al. 2014; Mathew et al. 2016). It is found that variability of the descending branch of the HC influences the sea level pressure and the sea surface wind fields. As a consequence, the wind shear between the low and high latitudes (i.e., zero WSC line) has moved poleward in recent decades. Studies based on satellite observations showed that both the surface Oyashio Extension (OE) front (Wu et al. 2018, 2019) and the surface subtropical fronts (referred to KE front; Yang et al. 2020a) have shifted northward associated with the poleward shift of the subtropical gyre in the last four decades.
Despite the surface evidence, few studies have examined the change in the subsurface KE front during the poleward expansion of the $\mathrm{HC}$ and whether and how the formation of the STMW is affected. If the subsurface KE front was to move poleward in a similar manner to the surface portion, there would be substantial changes in the upper-ocean stratification in the STMW formation region (Joyce et al. 2009), which would affect the formation rate of the STMW.

This study aims to address the above question by using data that are available for the period from 1979 to 2018. This period is concurrent with the robust poleward expansion of the $\mathrm{HC}$ (e.g., Seidel et al. 2008). The focal domain is the KE and the STMW formation region $\left(130^{\circ} \mathrm{E}-180^{\circ}, 20^{\circ}-40^{\circ} \mathrm{N}\right)$ in the upper $500 \mathrm{~m}$. The rest of this paper is organized as follows. Section 2 describes the datasets and methods used to identify the KE front position and calculate the STMW subduction rate. In section 3, we investigate the poleward shift of the KE front, related changes in the STMW formation area and $h_{m}$, and their effects on the mode water formation rate. Discussion and summary are included in section 4 .

\section{Data and methods}

\section{a. Definition of the KE front position}

The KE front is characterized by strong SSH gradients or by temperature gradients in the subsurface ocean (Joyce et al. 2009). Several metrics have been used to position the KE front, including the temperature gradients, the isotherms at specific depth, and the pertinent SSH contours along or near the local $\mathrm{SSH}$ gradient maxima. The datasets and methods used in this study to identify the KE front position are listed in Table 1 . The data source (in situ profile data) of gridded products used in this study are basically from the World Ocean Database (WOD) with a very small number of additional data by each data center [see Ishii et al. (2017), Good et al. (2013), and Cheng et al. (2017) for more details]. The data coverage is calculated by using in situ profiles from the WOD in $1^{\circ} \times$ $1^{\circ}$ boxes from surface to $500 \mathrm{~m}$, with layer interval of $20 \mathrm{~m}$ for every month. Figure 2 shows the data coverage in the past 70 years in the study area and it increases remarkably (mostly $90 \%-100 \%$ coverage) after 1979 , so that we could characterize the surface and subsurface KE front. Here, it should be noted that this study does not involve the local eddy effect (Qiu and Chen 2006; Wen et al. 2019), because the eddy activity in the $\mathrm{KE}$ region cannot be reproduced well with the datasets we used.

The surface KE front is often defined by the maximum horizontal SST gradients (e.g., Seo et al. 2014; Yang et al. 2020a), the maximum horizontal SSH gradients (e.g., Nonaka et al. 2006), and the selected SSH isolines (e.g., Qiu and Chen 2005; Seo et al. 2014) (Figs. 3a-c). The high-resolution $\left(0.25^{\circ} \times 0.25^{\circ}\right)$ SST product is the monthly National Oceanic and Atmospheric Administration Optimum Interpolation SST Analysis version 2 (NOAA OISSTv2, September 1981-December 2018) (Reynolds et al. 2007). Two SST fronts in the North Pacific are shown in Fig. 3a. One is the OE front located along $\sim 41^{\circ} \mathrm{N}$ and the other is the $\mathrm{KE}$ front along $\sim 35^{\circ} \mathrm{N}$. The latter is studied in this 


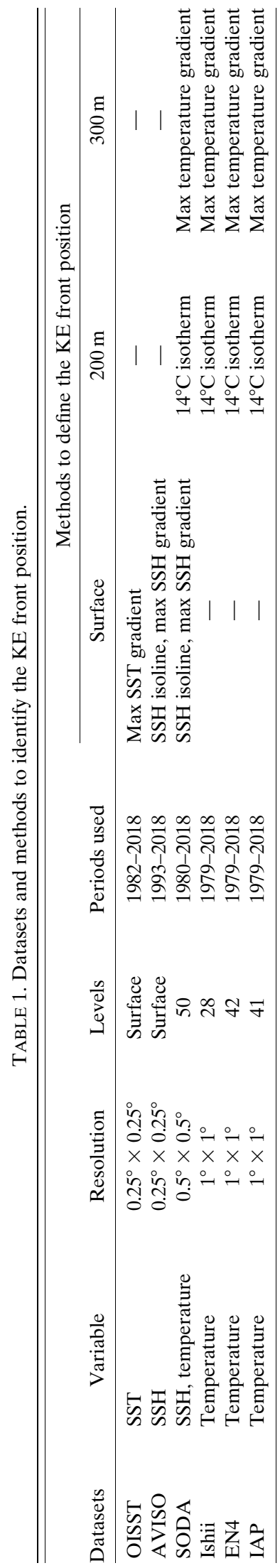

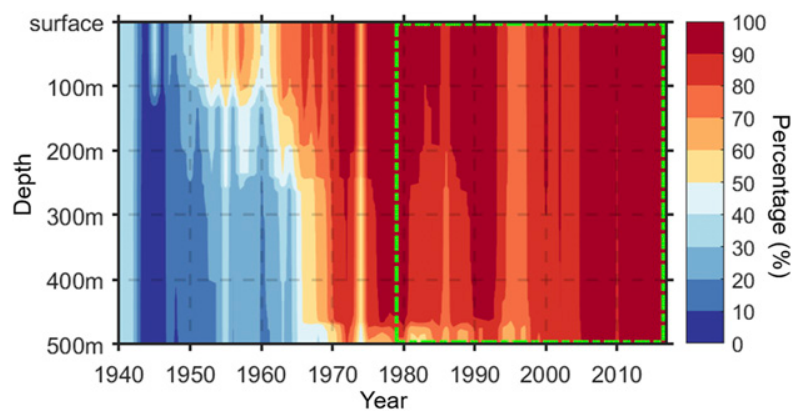

FIG. 2. Percentage $(\%)$ of data coverage for $1^{\circ} \times 1^{\circ}$ boxes over the KE and the STMW formation region $\left(130^{\circ} \mathrm{E}-180^{\circ}, 20^{\circ}-40^{\circ} \mathrm{N}\right)$ from the surface to $500 \mathrm{~m}$. The green dot-dashed box indicates the data coverage during 1979-2018, which is the period focused on in this study. More details are shown in section 1.

paper. Following Seo et al. (2014), the KE front position is defined by the 110-cm SSH isoline that was reconstructed by adding the satellite altimetry dataset from AVISO (Ducet et al. 2000) to the mean dynamic topography (Fig. 3b). The shorter observation period of the AVISO data (1992-present) is not sufficient for quantifying the long-term variation of the KE front in recent 40 years. To study the long-term trend of the KE front position, we resort to the 50-cm SSH contour from the Simple Ocean Data Assimilation (SODA) version 3.4.2 (Carton et al. 2018a,b) (Fig. 3c). The ocean reanalysis product SODA has a 50-level vertical grid and has been remapped onto a regular $0.5^{\circ} \times 0.5^{\circ}$ Mercator horizontal resolution for the period of 1980-2018. As shown in Figs. 3b and 3c, both the 110-cm SSH (AVISO) and the 50-cm SSH (SODA) contours are consistently located in the vicinity of the maximum SSH gradient. In the following analysis, we reduce the original resolution of the AVISO $\left(0.25^{\circ}\right)$ to $0.5^{\circ}$ resolution by selecting the data at every two grid points both in the zonal and meridional directions, following Nonaka et al. (2006), to minimize the influence of ocean eddies. The reduced resolution does not affect the frontal fine structures in the KE region (Fig. 3c). The SSH values from AVISO and SODA are also detrended with their respective global mean trend (Chen et al. 2017; Wu et al. 2019) to minimize the global warming effect.

To locate the subsurface KE front position, three observational datasets (referred as the Ishii data, EN4 data, and IAP data) are used in addition to the SODA data. Ishii data used in this study are an updated version that extends from 1955 to 2018 (Ishii et al. 2017). The EN4 data (version EN.4.2.1-analyses-g10) are produced by the Met Office Hadley Centre (Good et al. 2013) for the period of 1940-2018. The IAP data are the product by Institute of Atmospheric Physics, Chinese Academy of Sciences (Cheng et al. 2017) for 19402018. All the three datasets are global gridded $\left(1^{\circ} \times 1^{\circ}\right)$ monthly objective analyses of quality-controlled in situ observations obtained from all types of ocean profiling instruments. Note that the three observational datasets may not adequately address the surface KE front variability (e.g., Fig. 3d) because of the strong spatial smoothing, they appear to be sufficient to capture the subsurface KE front in a manner similar to the SODA data (Fig. 4). 

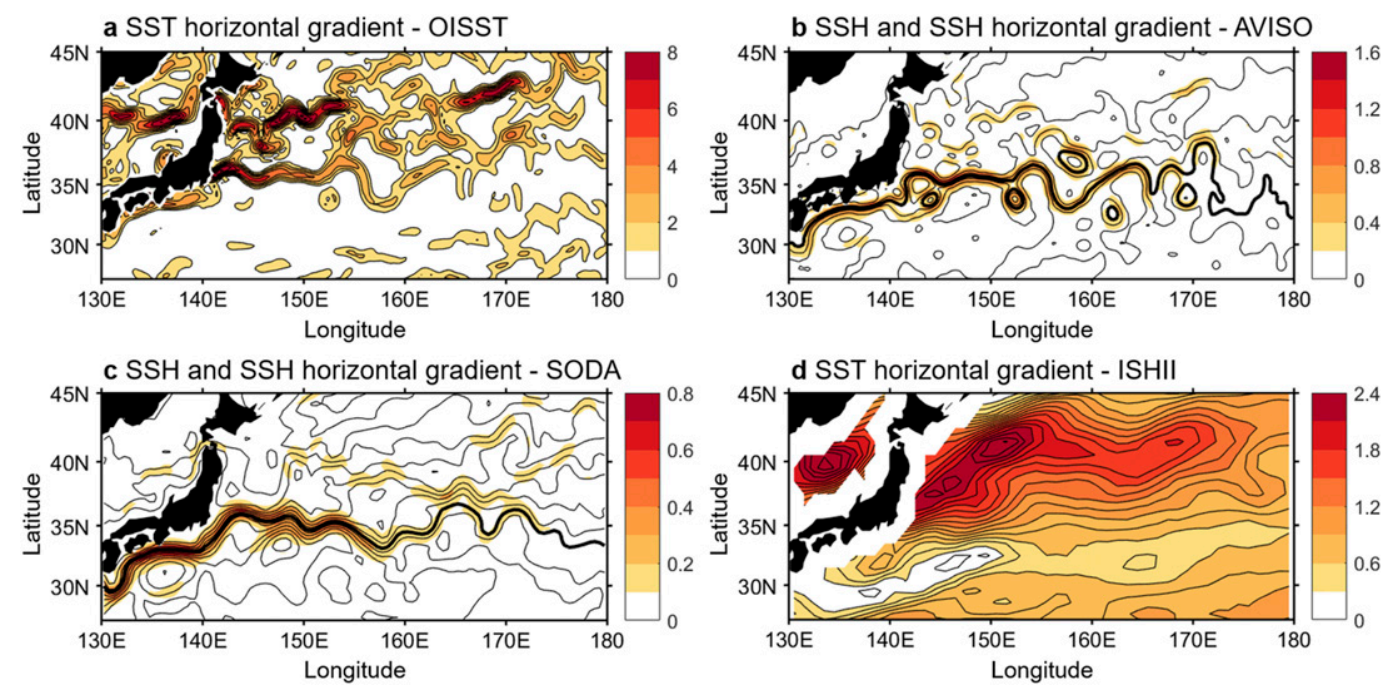

FIG. 3. Definition of the surface KE front position with different datasets and methods. (a) Horizontal SST gradient $\left[{ }^{\circ} \mathrm{C}(100 \mathrm{~km})^{-1}\right.$ ] from NOAA OISST, (b) SSH ( $\mathrm{m}$; contours with an interval of $\left.0.2 \mathrm{~m}\right)$ and SSH horizontal gradient [color; $\mathrm{m}(100 \mathrm{~km})^{-1}$ ] from AVISO, (c) SSH ( $\mathrm{m}$; contours with an interval of $\left.0.1 \mathrm{~m}\right)$ and SSH horizontal gradient [color; $\mathrm{m}(100 \mathrm{~km})^{-1}$ ] from SODA, and (d) horizontal SST gradient $\left[{ }^{\circ} \mathrm{C}(100 \mathrm{~km})^{-1}\right.$ ] from Ishii data in January 2010. The thick black line in (b) and (c) indicates the 110- and 50-cm SSH contour, respectively (see details in the text).

The meridional temperature gradient shows that the OE front is clearly seen from the surface down to about 200-m depth and the KE front is more obvious between 200 and $500 \mathrm{~m}$ (Figs. 4a,b). To minimize the impact of the OE front at $200 \mathrm{~m}$, the $\mathrm{KE}$ front position is detected by the $14^{\circ} \mathrm{C}$ isotherm (Joyce et al. 2009; Frankignoul et al. 2011), instead of the temperature gradient method. Consistency among the definitions of the KE front at $200 \mathrm{~m}$ can be confirmed using the climatological vertical velocity structure (Fig. $4 \mathrm{c}$ ), in which the $14^{\circ} \mathrm{C}$ isotherm and the maximum meridional temperature gradient roughly correspond to the largest zonal current velocity along the $\mathrm{KE}$ front. At the depth of $300 \mathrm{~m}$, the maximum meridional temperature gradient is used for locating the KE front (Nonaka et al. 2006). Since the maximum $h_{m}$ in this region is about $300 \mathrm{~m}$ and the subsurface KE front is concentrated on the upper $300 \mathrm{~m}$ (Fig. 4), the change of the KE front in the upper $300 \mathrm{~m}$ is analyzed.

It is noted that the KE front is regarded as a density front rather than a temperature front (Figs. $4 \mathrm{~d}$,e). The use of temperature instead of density to locate the KE front stems from the consideration that temperature dominates the density change in the region (Johnson et al. 2012) and that salinity observations are limited. While more in-depth discussions are needed for the definitions of the KE front, all the aforementioned metrics are appropriate as reviewed by Kida et al. (2015). The KE front position is calculated in the domain of $142^{\circ}-165^{\circ} \mathrm{E}$ and $32^{\circ}-37^{\circ} \mathrm{N}$ and the analysis period of this study is 40 winters (January-March) during 1979-2018, because the KE front is strongest and the robust SST front can be observed during wintertime.

\section{b. Calculation of the subduction rate}

The STMW is defined as the water mass that has temperature ranging between $16^{\circ}$ and $18^{\circ} \mathrm{C}$, the layer thickness greater than $50 \mathrm{~m}$, and a vertical temperature gradient less than $1.5^{\circ} \mathrm{C}$ $(100 \mathrm{~m})^{-1}$ (Wu et al. 2020a). Even though the mean temperature of the STMW has increased during the past 40 years (Sugimoto et al. 2017), the use of a fixed temperature (i.e., $16^{\circ}-18^{\circ} \mathrm{C}$ ) for the STMW is deemed appropriate. Figure 5a shows the volume distribution of each temperatures with the range between $14^{\circ}$ and $20^{\circ} \mathrm{C}$ with $0.2^{\circ} \mathrm{C}$ interval. It was calculated from the temperature fields in the upper $500 \mathrm{~m}$ within the STMW formation and subduction area $\left(130^{\circ} \mathrm{E}-180^{\circ}, 20^{\circ}-37^{\circ} \mathrm{N}\right)$ during 1979-2018. It can be readily seen that the STMW, which is originally defined by the maximum volume within a selected temperature range (i.e., vertically homogeneous with small vertical temperature gradient) in the thermocline, is located primarily between the $16^{\circ}$ and $18^{\circ} \mathrm{C}$ isotherms (Figs. 5a,b). A similar fixed temperature range $\left(15^{\circ}-20^{\circ} \mathrm{C}\right)$ was also used by Sugimoto et al. (2017) and others (e.g., Oka et al. 2015; Sugimoto and Kako 2016; Wu et al. 2020a) to study the variability of the STMW. As shown in Fig. 5c, the volume percentage (denominator is the water volume in the upper $500 \mathrm{~m}$ within the mode water formation and subduction region, $130^{\circ} \mathrm{E}-180^{\circ}, 20^{\circ}-37^{\circ} \mathrm{N}$ ) of the $16^{\circ}-18^{\circ} \mathrm{C}$ isotherms shows no obvious trend and varies consistently with that of the $15^{\circ}-20^{\circ} \mathrm{C}$ isotherms. It appears that the global warming may have affected the mean temperature of the STMW, but a fixed temperature range, such as $16^{\circ}-18^{\circ} \mathrm{C}$, is able to represent the STMW variation throughout the study period. Other temperature ranges such as $15^{\circ}-20^{\circ} \mathrm{C}$ were also tested, and similar results were obtained.

The subduction rate is defined as the rate at which mixedlayer fluid is transferred into the permanent thermocline. By definition, the instant subduction rate $S(t)$ in the Eulerian coordinates is written as (Cushman-Roisin 1987; Williams et al. 1995) 

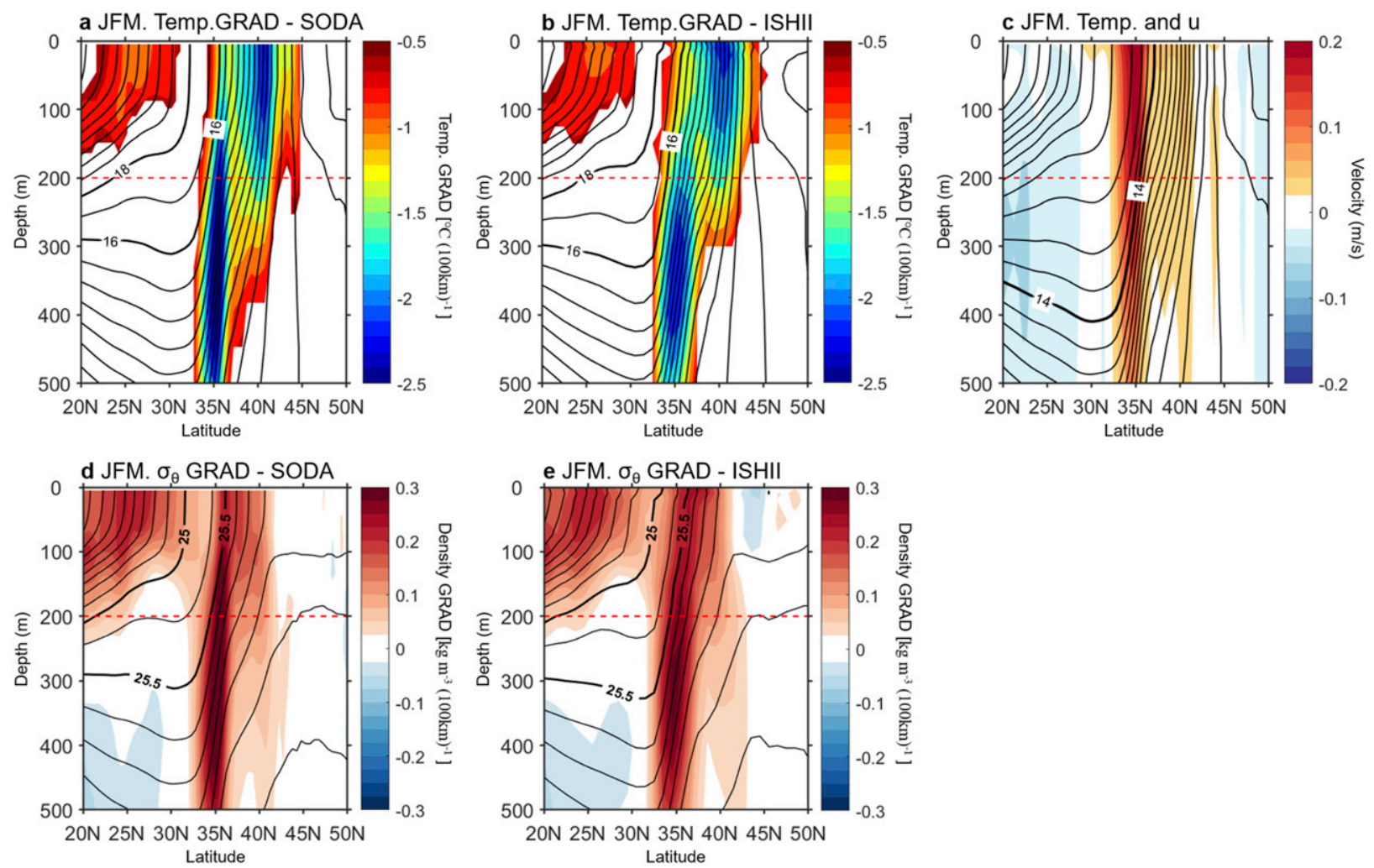

FIG. 4. Latitude-depth sections of climatological-mean January-March temperature (contours) and its meridional gradient [color; ${ }^{\circ} \mathrm{C}(100 \mathrm{~km})^{-1}$ ] averaged between $142^{\circ}$ and $165^{\circ} \mathrm{E}$, based on the (a) SODA and (b) Ishii datasets. (c) As in (a), but for the zonal current velocity $\left(\mathrm{m} \mathrm{s}^{-1}\right)$ from SODA. (d),(e) As in (a) and (b), but for the potential density $\left(\sigma_{\theta}\right.$; contours) and its meridional gradient $\left[\right.$ color; $\mathrm{kg} \mathrm{m}^{-3}\left(100 \mathrm{~km}^{-1}\right]$. Contour intervals for temperature field are $1^{\circ} \mathrm{C}$ and for density field are $0.25 \mathrm{~kg} \mathrm{~m}^{-3}$. Red dashed lines are the depth at $200 \mathrm{~m}$.

$$
S(t)=-\left(\frac{\partial h_{m}}{\partial t}+\mathbf{u}_{\mathrm{mb}} \cdot \nabla h_{m}+w_{\mathrm{mb}}\right),
$$

where the subscript mb denotes the mixed layer base; $S(t)$ is the sum of the vertical velocity at the base of the mixed layer $\left(-w_{\mathrm{mb}}\right)$, the rate at which the water is swept beneath the shoaling mixed layer base by horizontal currents $\left(-\mathbf{u}_{\mathrm{mb}} \cdot \nabla h_{m}\right)$, and the rate of the mixed layer shallowing $\left(-\partial h_{m} / \partial t\right) ; h_{m}$ is defined as the depth at which the potential density is $0.125 \mathrm{~kg} \mathrm{~m}^{-3}$ higher than the surface density and is derived from Ishii data; and $\mathbf{u}_{\mathrm{mb}}$ is computed from the thermal wind equations using the temperature and salinity from the Ishii data. We assumed a level of no motion at 2000-m depth. The velocity $w_{\mathrm{mb}}$ is computed from wind stress using the European Centre for Medium-Range Weather Forecast interim reanalysis (ERA-Interim; Dee et al. 2011). The monthly ERA-Interim wind stress data are from 1979 to present, interpolated into $0.25^{\circ} \times 0.25^{\circ}$ (latitude $\times$ longitude) spatial resolution. Since the instantaneous subduction rate fluctuates considerably, it is more meaningful to use the annual mean subduction rate $S_{\text {ann }}$ defined as

$$
\begin{aligned}
S_{\mathrm{ann}} & =\frac{1}{T} \int_{T_{s}^{\mathrm{ef}}}^{T_{e}^{\mathrm{ef}}} S(t) d t \\
& =-\frac{1}{T} \int_{T_{s}^{\mathrm{ef}}}^{T_{e}^{\mathrm{ef}}} w_{\mathrm{mb}} d t-\frac{1}{T} \int_{T_{s}^{\mathrm{ef}}}^{T_{e}^{\mathrm{ef}}}\left(\mathbf{u}_{\mathrm{mb}} \cdot \nabla h_{m}+\frac{\partial h_{m}}{\partial t}\right) d t,
\end{aligned}
$$

where $T$ is one year, and $T_{s}^{\mathrm{ef}}$ and $T_{e}^{\mathrm{ef}}$ are the times when effective detrainment starts and ends, respectively. The first term on the right-hand side represents the contribution from vertical pumping at the base of the mixed layer, and the second term indicates the contribution from lateral/temporal induction due to the sloping mixed layer base.

Winter means are constructed from monthly means by averaging the data from January to March. The 5\% significance level is used for all statistical analysis calculated following Bretherton et al. (1999).

\section{Results}

\section{a. Poleward shift of the KE front}

The mean position of the surface KE front agrees well with the classical picture (Mizuno and White 1983), featuring two quasi-stationary meanders with ridges centered at $143^{\circ}$ and $150^{\circ} \mathrm{E}$ (Fig. 1). For the subsurface KE front, the meridional sections of wintertime climatological temperature and its meridional gradient based on the SODA and Ishii data are shown (Figs. 4a,b). The strong meridional temperature gradient associated with the subsurface $\mathrm{KE}$ front around $35^{\circ} \mathrm{N}$ was well reproduced, both in the reanalysis and the observed climatology.

The differences in the surface-to-subsurface KE front between the two periods, 1980-89 and 2009-18 can be generally 

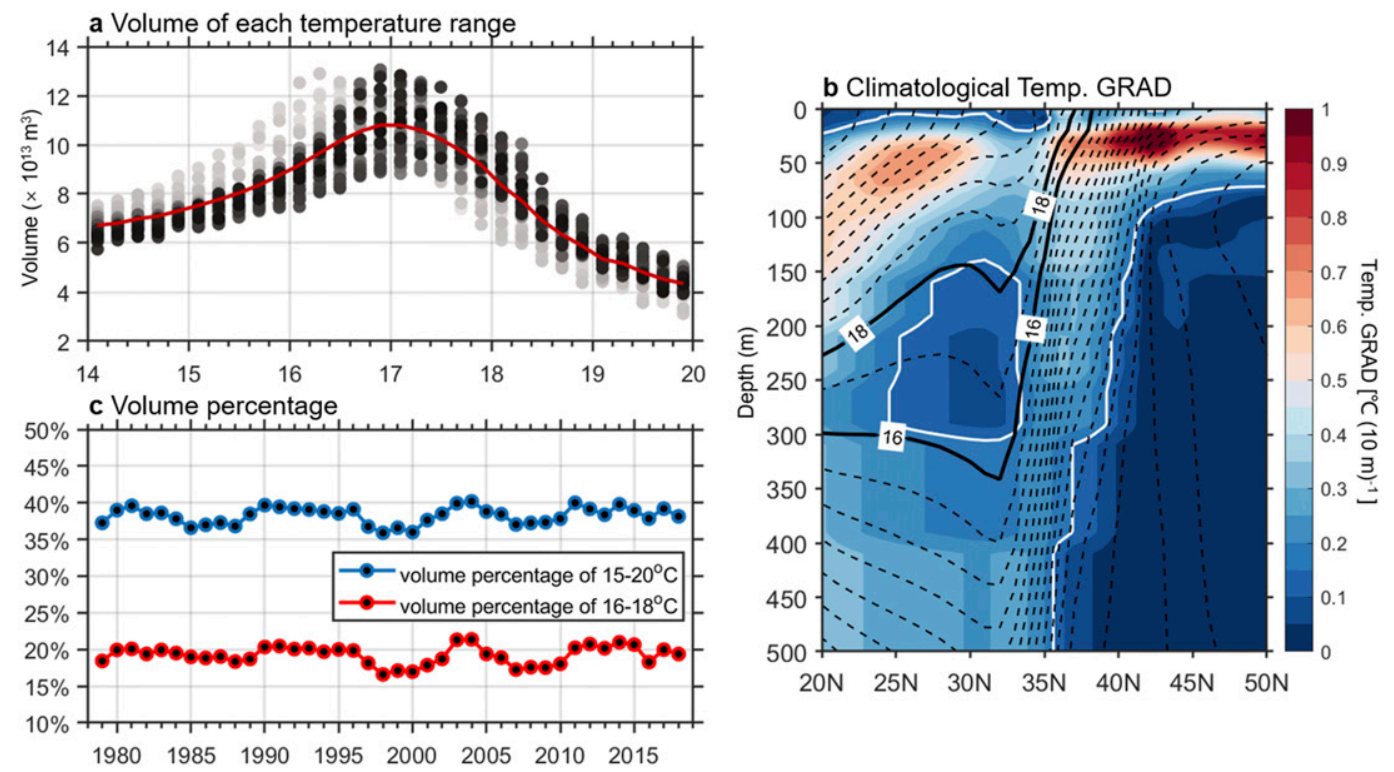

FIG. 5. (a) The volume $\left(\times 10^{13} \mathrm{~m}^{3}\right)$ of each temperature range between $14^{\circ}$ and $20^{\circ} \mathrm{C}$, with a $0.2^{\circ} \mathrm{C}$ interval, which is calculated in the STMW formation and subduction area $\left(130^{\circ} \mathrm{E}-180^{\circ}, 20^{\circ}-37^{\circ} \mathrm{N}\right)$ in the upper $500 \mathrm{~m}$ for 40 years by using annual mean temperature. Dots from light to dark colors indicate the results from 1979 to 2018, and red line shows the mean value. (b) Climatological temperature (contours; ${ }^{\circ} \mathrm{C}$ ) and its vertical gradient [shading; ${ }^{\circ} \mathrm{C}(10 \mathrm{~m})^{-1}$ ] averaged between $141^{\circ}$ and $155^{\circ} \mathrm{E}$ derived from the Ishii data. The marked $16^{\circ}$ and $18^{\circ} \mathrm{C}$ contours are the defined lower and upper temperature boundaries of the mode water. The white contour is the $1.5^{\circ} \mathrm{C}(100 \mathrm{~m})^{-1}$ line, which is the vertical temperature gradient criterion of the mode water. (c) Volume percentages of the $15^{\circ}-20^{\circ} \mathrm{C}$ and $16^{\circ}-18^{\circ} \mathrm{C}$ in the STMW formation and subduction area $\left(130^{\circ} \mathrm{E}-180^{\circ}, 20^{\circ}-37^{\circ} \mathrm{N}\right)$ in the upper $500 \mathrm{~m}$ during 1979-2018. The data analyzed here are from Ishii data.

regarded as the long-term trend of the KE front shift in the past 40 years. Figure 6 displays the meridional sections of temperature (contours) and the meridional temperature gradient (color shading) that were constructed from zonal averages between $142^{\circ}$ and $165^{\circ} \mathrm{E}$ for the two periods, $1980-89$ and 2009-18, respectively. The left panels are based on the SODA data (Figs. 6a-c), showing that the northward migration of the KE front, as well as the intensification of the KE front (color shading in Fig. 6c), has occurred both at the surface and in the subsurface layers. The right panels in Fig. 6 are based on the Ishii observational dataset that has a coarser resolution $\left(1^{\circ} \times 1^{\circ}\right)$. As a result, the KE front is relatively broader and weaker compared to that from the SODA dataset (Figs. 6d,e). Nevertheless, major features associated with the northward shift and enhancement of the meridional temperature gradient of the KE front are still shown, including the intensified $\mathrm{KE}$ front, the higher temperature anomalies, and downward displacement of the thermocline (Fig. 6f).

To examine the meridional shift of the KE front at different layers, time series of the zonally averaged $\left(142^{\circ}-165^{\circ} \mathrm{E}\right) \mathrm{KE}$ front positions at the surface, $200 \mathrm{~m}$, and $300 \mathrm{~m}$ are shown in Fig. 7. It is evident that the $\mathrm{KE}$ front variability is coherent from the surface (Figs. 7a,b) to subsurface (200 and $300 \mathrm{~m}$; Figs. 7c,d) on interannual to decadal time scales, although the magnitude of the change varies with depth. At the surface, the KE front position based on the maximum horizontal SST gradient method (Fig. 7a) is located north of the front position based on the SSH definitions (Fig. 7b) by about $0.5^{\circ}$ in latitude
(Seo et al. 2014). The surface KE front defined by the maximum horizontal SSH gradient (orange and red points in Fig. 7b) agrees well with that based on specific SSH isoline (blue and gray points in Fig. 7b). Although there are uncertainties among different datasets and different definitions of the KE front, the results are convergent in showing that the KE front has shifted poleward. The rate of the shift is $\sim 0.23^{\circ} \pm 0.17^{\circ} \mathrm{decade}^{-1}$ based on the SST gradient method and $\sim 0.25^{\circ} \pm 0.15^{\circ}$ decade $^{-1}$ based on the SSH methods.

The long-term trend of the poleward shift of the surface KE front shows two different behaviors before and after 2002 (Figs. 7a,b). During the first period from 1979 to 2002 , the surface KE front moved northward at a rate of $\sim 0.38^{\circ} \pm 0.22^{\circ}$ decade $^{-1}$ based on the SST gradient method and $\sim 0.32^{\circ} \pm 0.19^{\circ}$ decade $^{-1}$ based on the SSH methods, which is faster than the mean rate in the 40 -yr period. During the second period after 2002, there was substantial interannual variability but no clear decadal trend. Hence, the long-term poleward shift of the surface KE front in the past 40 years mainly occurred during 1979-2002. The time series of the latitudinal position of the surface KE front also showed strong variability on interannual to decadal time scales. There was a north-south movement of up to $2^{\circ}$ in latitude on time scale of 10-15 years (Figs. 7a,b). For instance, the KE front was located in relatively southward latitudes in years around 1980, 1995, 2005 , and 2015, but more northward latitudes in the early 1990s, 2000s, and 2010s. This movement is in agreement with previous studies [e.g., Fig. 3 in Qiu et al. (2017); Fig. 5a in 

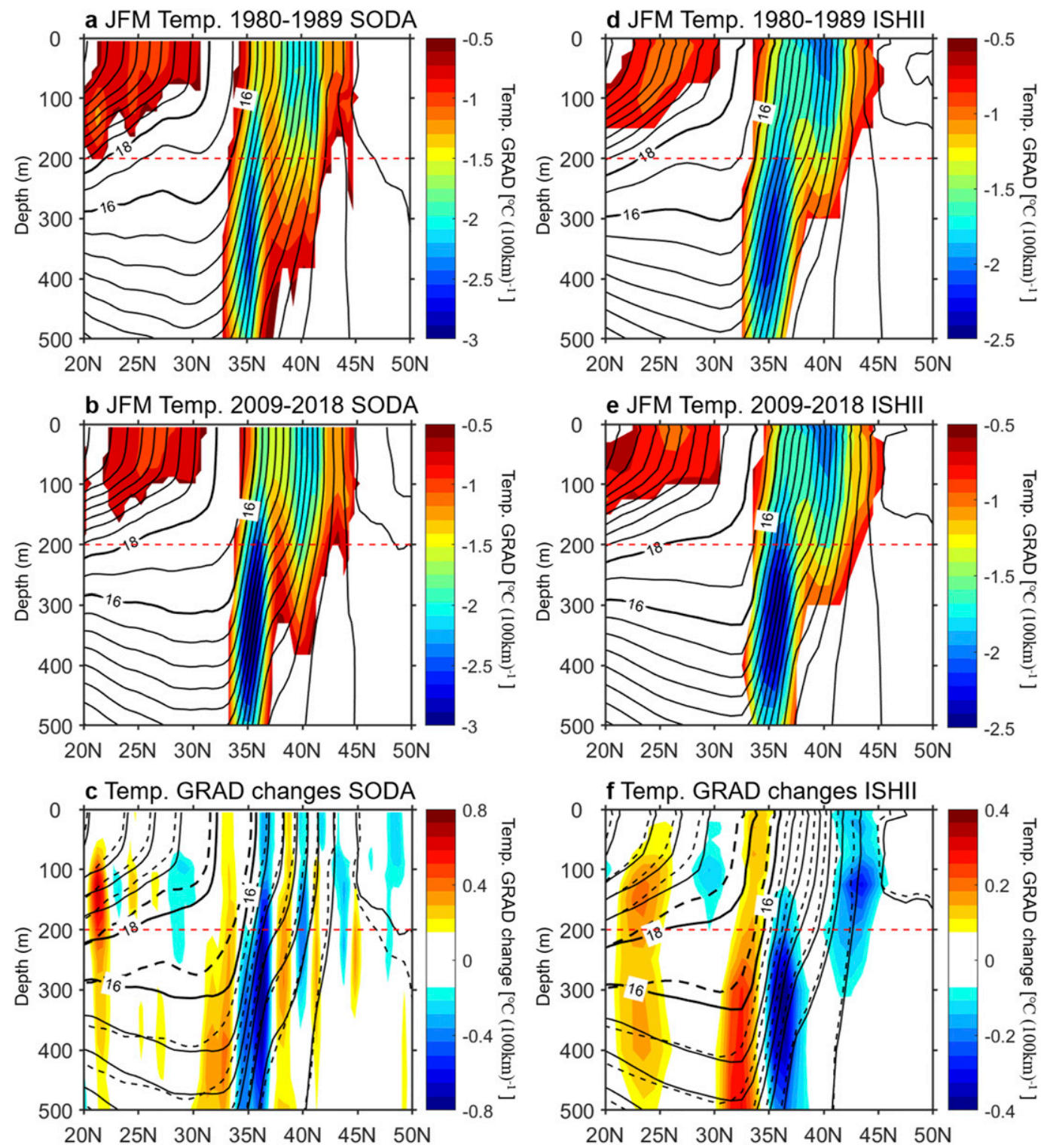

FIG. 6. Latitude-depth sections of 10 winter-mean (January-March) fields of temperature (contours) and its meridional gradient [color; ${ }^{\circ} \mathrm{C}(100 \mathrm{~km})^{-1}$ ] averaged between $142^{\circ}$ and $165^{\circ} \mathrm{E}$ for (a) $1980-89$ and (b) $2009-18$. (c) The winter-mean (January-March) temperature during 1979-88 (black dashed contours) and 2009-18 (black solid contours) with mean meridional temperature changes between the two decades in the background (color). Contour intervals for temperature field in (a) and (b) are $1^{\circ} \mathrm{C}$ and in (c) are $2^{\circ} \mathrm{C}$. The results from the (left) SODA and (right) Ishii datasets. Red lines are the depth at $200 \mathrm{~m}$.

Yang et al. (2020a)]. Observational and numerical studies have shown that the surface KE front exhibits a long-term shift (Yang et al. 2020a) and low-frequency north-south movement (Qiu and Chen 2005; Joyce et al. 2009; Frankignoul et al. 2011; Seo et al. 2014; Qiu et al. 2017), with a meridional displacement of about $200 \mathrm{~km}$ (Qiu and Chen 2010). Our results are not only consistent with these studies but also enhance them by showing the decadal differences of the shift before and after 2002.

Characteristics of the shift in the subsurface KE front are different from those in the surface. The four datasets examined in this study show that the northward movement of the subsurface KE front was more persistent with a lesser degree of interannual to decadal variability (Figs. 7c,d). Unlike the surface $\mathrm{KE}$ front that showed the shift changed the pace before and after 2002, the subsurface KE front continued to shift poleward after 2002. The overall mean trend of the KE front meridional shift at the depths of 200 and $300 \mathrm{~m}$ are $0.21^{\circ} \pm$ $0.13^{\circ}$ decade $^{-1}$ and $0.23^{\circ} \pm 0.18^{\circ}$ decade $^{-1}$, respectively. Note that the subsurface $\mathrm{KE}$ front at $200 \mathrm{~m}$ was derived from the $14^{\circ} \mathrm{C}$ isotherm and the front at $300 \mathrm{~m}$ was identified using the maximum meridional temperature gradients. These definitions 

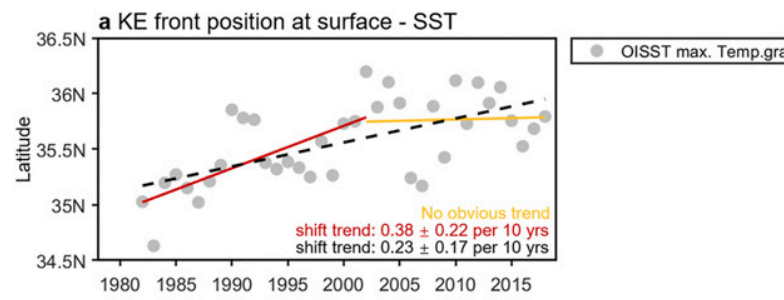

b KE front position at surface - SSH
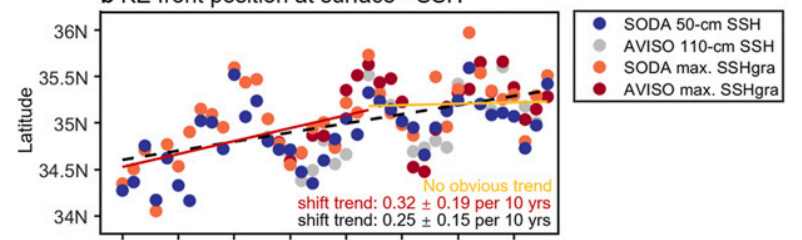

- AVISO max. SSHgra

$\begin{array}{llllllll}1980 & 1985 & 1990 & 1995 \quad 2000 & 2005 & 2010 \quad 2015\end{array}$

c KE front position at $200 \mathrm{~m}$
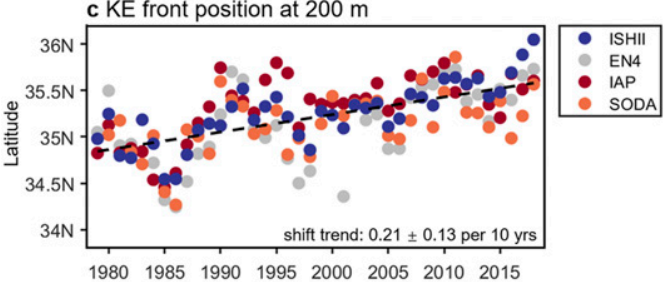

d KE front position at $300 \mathrm{~m}$

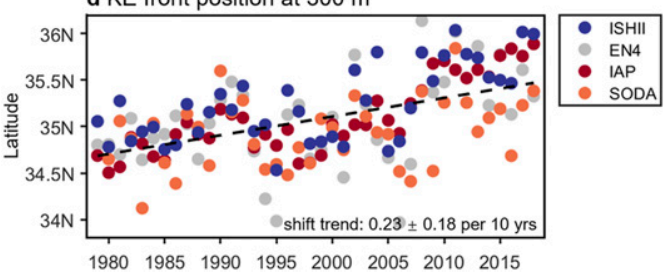

FIG. 7. Time series of the winter-mean (January-March) meridional shift of the $\mathrm{KE}$ front position averaged between $142^{\circ}$ and $165^{\circ} \mathrm{E}$ and its mean trend (black dashed line) at the surface with (a) SST method and (b) SSH methods, and at (c) $200 \mathrm{~m}$ and (d) $300 \mathrm{~m}$ based on different datasets and methods as indicated by the legends. Please see the text and Table 1 for more details. The red line and yellow lines in (a) and (b) indicate the surface KE front shift trend before and after 2002, respectively. The trends are all statistically significant above the $95 \%$ confidence level.

are different from the surface KE front definitions, which may cause a reduction of the subsurface KE front variability.

\section{b. Changes in the ventilation zone and the upper-layer stratification}

The ventilation zone of the STMW, defined by the area between $16^{\circ}$ and $18^{\circ} \mathrm{C}$ isotherms (or between 25 and $25.5 \mathrm{~kg} \mathrm{~m}^{-3}$ isopycnals), and the $h_{m}$ in the STMW formation region are closely related to the upper-ocean stratification. Two sets of metrics are used to describe the long-term change of the STMW ventilation zone (Fig. 8a): the mean temperature pattern for two decades, 1980-89 and 2009-18 (donated by the respective dashed and solid contours), and the mean temperature changes between the two 10-yr epochs (denoted by the colored background). It is evident that the isotherms have migrated northward from the earlier period to the later period, but with different amplitudes for different isotherms. The magnitude of the latitudinal shift was quantified using the isotherms averaged between $142^{\circ}$ and $165^{\circ} \mathrm{E}$ (Fig. 8b). For the meandering path of a certain isotherm, we used its averaged position in this study. The total shift in latitude increases from the $12^{\circ}$ to $18^{\circ} \mathrm{C}$ isotherm: smallest for the $12^{\circ} \mathrm{C}$ isotherm with a magnitude of $0.32^{\circ} \pm 0.20^{\circ}$, and greatest for the $18^{\circ} \mathrm{C}$ isotherm with a magnitude of $2.17^{\circ} \pm$ $0.73^{\circ}$. Hence, in the KE frontal region, the southern isotherms have moved farther poleward than the northern isotherms, strengthening the poleward shift of the maximum SST gradients and thus the surface KE front (Fig. 7a). During this transition, the edge of the STMW outcrop $\left(130^{\circ} \mathrm{E}-180^{\circ}\right)$ has also moved northward as indicated by the $16^{\circ}$ and $18^{\circ} \mathrm{C}$ isotherms, with a magnitude of $1.37^{\circ} \pm 0.51^{\circ}$ and $2.21^{\circ} \pm 0.70^{\circ}$ in latitude, respectively. This suggests that the STMW ventilation zone has contracted in the past 40 years.

The shift of the STMW ventilation zone is examined in the density coordinate in Figs. 8c and 8d. Characteristics of the shift in the density coordinate are similar to those in the temperature coordinate. For instance, larger negative density anomalies (less dense) were located to the south of the KE front (Fig. 8c) and the northward shift increased from 26 to $25 \mathrm{~kg} \mathrm{~m}^{-3}$ (Fig. 8d). The edge of the STMW ventilation zone confined between 25.5 and $25 \mathrm{~kg} \mathrm{~m}^{-3}$ isopycnals (corresponding to the $16^{\circ}$ and $18^{\circ} \mathrm{C}$ isotherms) has shifted poleward by $1.59^{\circ} \pm 0.48^{\circ}$ and $2.20^{\circ} \pm 0.77^{\circ}$ latitude in total from 1979 to 2018 , which also indicates a contraction of the ventilation area. The spatial pattern and total northward shift are consistent in both temperature and density coordinates (Figs. 8a-d).

It is worth pointing out that the aforementioned decadal differences in the poleward shift of the surface KE front before and after 2002 led to differences in the variation of the ventilation zone between the two periods, 1979-2002 and 2002-18. Figures $8 \mathrm{e}-\mathrm{h}$ showed the changes of isotherms before and after 2002. Before 2002, there was a robust northward shift of the maximum SST gradient with SST anomalies higher in the south of KE than in the north of KE (Fig. 8e). There was also a greater poleward shift of the SST isotherms from $12^{\circ}$ to $18^{\circ} \mathrm{C}$ (Fig. 8f), along with a faster poleward shift of the surface $\mathrm{KE}$ front. After 2002, there were weak SST anomalies in the KE frontal region (Fig. $8 \mathrm{~g}$ ) and no significant shift of the isotherms (Fig. 8h). This corresponded well to the relatively stable surface $\mathrm{KE}$ front. It is interesting that the poleward shift of the $18^{\circ} \mathrm{C}$ isotherm was larger than that of $16^{\circ} \mathrm{C}$ isotherm during 1979-2002 but smaller or even slightly southward during 2002-18. This is supported by both satellite observations (OISST data) and in situ observations (Ishii data) (Fig. 9). Consequently, the ventilation zone contracted before 2002 and experienced no contraction after 2002, consistent with the trend changes of the surface KE front poleward shift (Figs. 7a,b).

The change of the $h_{m}$ is affected by the upper-ocean stratification. Stronger stratification is generally associated with shallower $h_{m}$. Before 2002, the warming in the surface layer was larger than that in the subsurface layer in the ventilation zone, so the stratification within $h_{m}$ over the formation region increased (Figs. 10a,b). After 2002, the surface KE front showed no obvious trend, showing no warming or weak cooling 

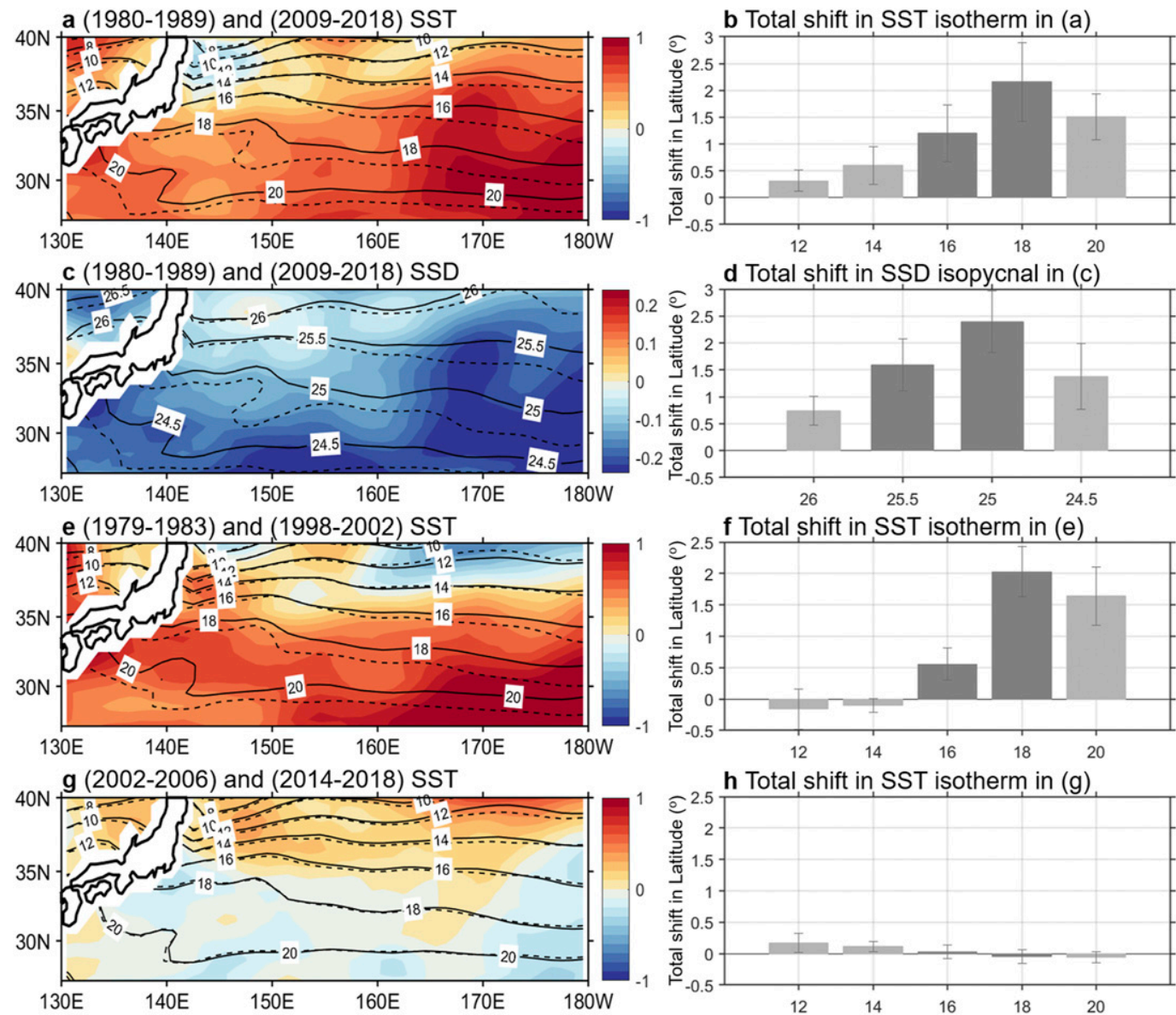

FIG. 8. (a) The winter-mean (January-March) SST in the subtropical North Pacific during 1980-89 (black dashed contours) and 2009-18 (black solid contours) with the SST mean changes between the two periods in the background (color). (b) The total shift in the positions of the selected SST isotherms between $142^{\circ}$ and $165^{\circ} \mathrm{E}$ during 1980-89 and 2009-18, with error bars denoting the 95\% confidence interval estimates. (c),(d) As in (a) and (b), but for the SSD. (e)-(h) As in (a) and (b), but for the SST during 1979-83 and 1998-2002 in (e) and (f), and 2002-06 and 2014-18 in $(\mathrm{g})$ and $(\mathrm{h})$. The $16^{\circ}-18^{\circ} \mathrm{C}$ isotherms and $25-25.5 \mathrm{~kg} \mathrm{~m}^{-3}$ isopycnals indicate the outcrop region of STMW in temperature and density coordinate, respectively. The data analyzed here are from Ishii data.

in surface layer (Fig. 10c). Meanwhile, the subsurface KE front continued to move northward, which led to an even weaker upper-ocean stratification (Fig. 10d). The stratification intensity (i.e., the mean value of the vertical temperature gradient) over the ventilation zone, which reflects the change of $h_{m}$ in the STMW formation region, increased before 2002 but remained nearly steady after 2002 (Figs. 10e,f).

\section{c. Changes in the formation of the STMW}

The contracted ventilation zone along with the increased upper-layer stratification would induce changes in the STMW subduction rate. To better understand the change, we first examined the climatological annual subduction rate and its three components, including the temporal induction, the lateral induction and the vertical pumping (Fig. 11). The spatial distribution of annual subduction rate is similar to that from observations or models (e.g., Fig. 11c in Qiu and Huang 1995; Fig. 6c in Qu et al. 2002; Fig. 4 in Liu and Huang 2012). There were two bands of local maximum in the western North Pacific. One was associated with the STMW between $20^{\circ}$ and $37^{\circ} \mathrm{N}$, and between $140^{\circ}$ and $170^{\circ} \mathrm{E}$, with magnitude exceeding $120 \mathrm{~m} \mathrm{yr}^{-1}$. The other was located at around $40^{\circ} \mathrm{N}$ that corresponds to the central mode water (Suga et al. 1997; Talley 1999). Farther to the east, a localized maximum occurred near $25^{\circ} \mathrm{N}, 150^{\circ}-120^{\circ} \mathrm{W}$, which is related to the North Pacific eastern subtropical mode water (Hautala and Roemmich 1998). The temporal induction was governed by the $h_{m}$ shoaling rate, being largest in the northwestern subtropical gyre with a magnitude exceeding $90 \mathrm{~m} \mathrm{yr}^{-1}$ (Fig. 11b), and decreasing rapidly toward the southeast. The lateral induction term produced no spatial pattern except for a few patches of localized maxima of about $30 \mathrm{~m} \mathrm{yr}^{-1}$ in the vicinity of the $\mathrm{KE}$ frontal region (Fig. 11c). The annual subduction rate due to the vertical pumping varies from 0 to $30 \mathrm{~m} \mathrm{yr}^{-1}$ (Fig. 11d) in the subtropical gyre. In general, the contribution from the temporal shoaling of the $h_{m}$ was dominant, while the contributions from the lateral induction and the vertical pumping terms were small. 

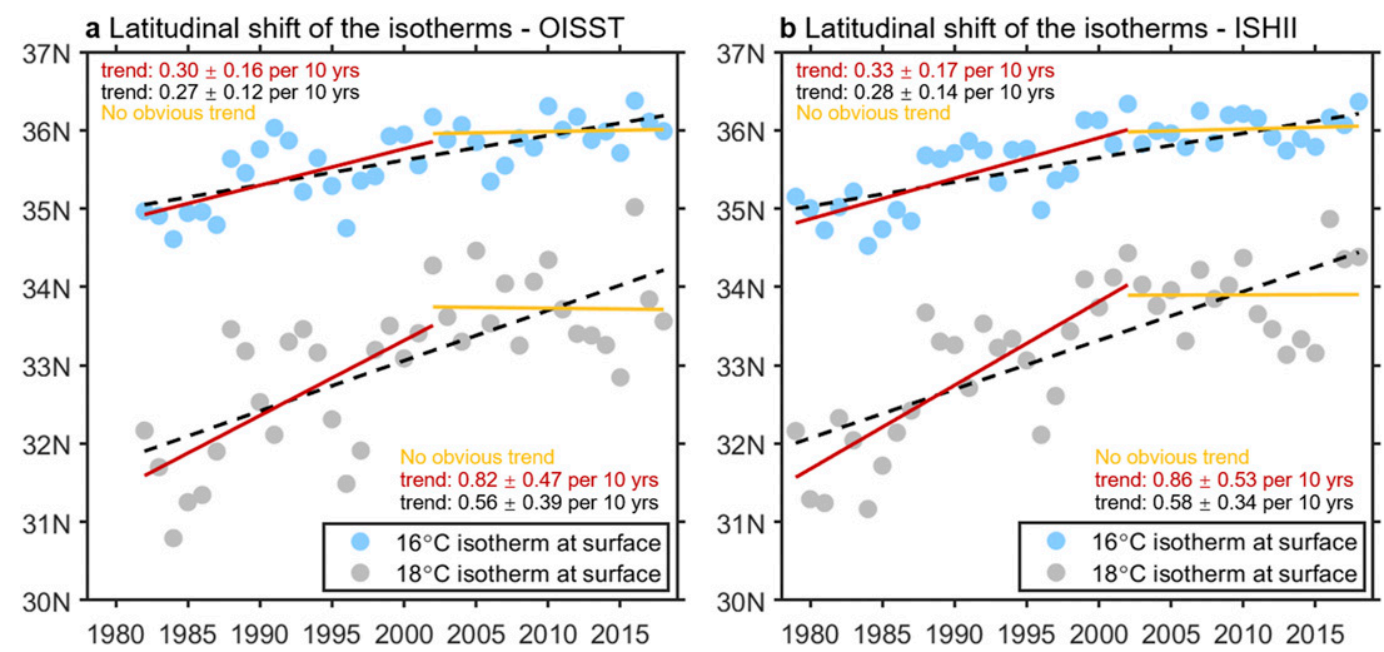

FIG. 9. (a) Latitudinal shift of the $16^{\circ} \mathrm{C}$ (blue) and $18^{\circ} \mathrm{C}$ (gray) isotherms between $142^{\circ}$ and $165^{\circ} \mathrm{E}$ during 1982-2018 and its trend (dashed black line is for 1982-2018, red line is for 1982-2002, and yellow line is for 2002-18) derived from OISST data. (b) As in (a), but derived from Ishii data during 1979-2018.

We then analyzed the decadal changes in $S_{\text {ann }}$ and its components by using the decadal contrasts between the two periods, 1980-89 and 2009-18 (Fig. 12). Compared to the early period (1980-89), the $S_{\text {ann }}$ in later period (2009-18) was much weaker (Fig. 12a) with broad negative anomalies, $\sim-50 \mathrm{~m} \mathrm{yr}^{-1}$, in the STMW formation and subduction area. The temporal induction term had negative anomaly pattern and magnitude similar to the $S_{\text {ann }}$ and was the leading contributor to the $S_{\text {ann }}$
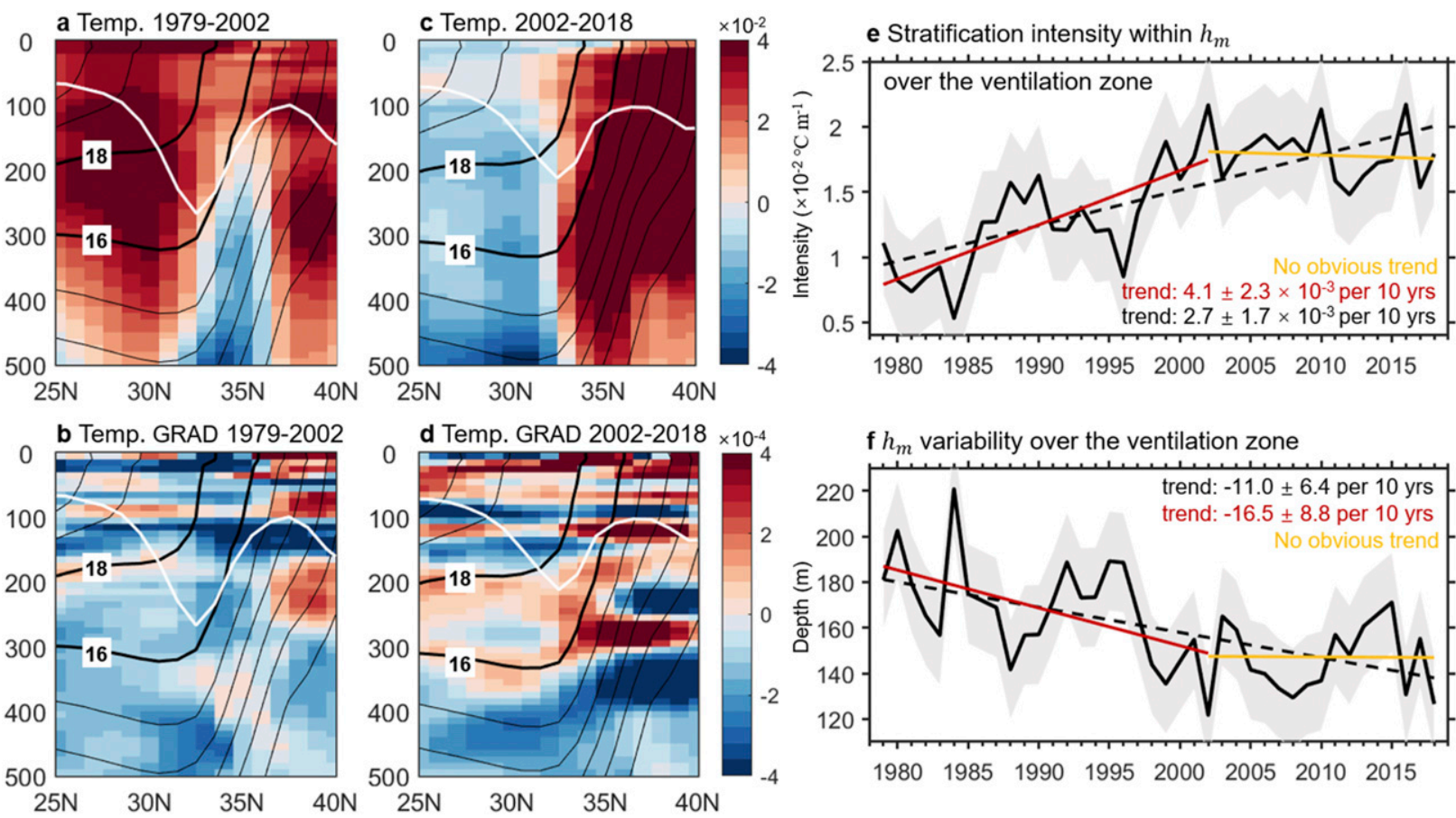

f $h_{m}$ variability over the ventilation zone

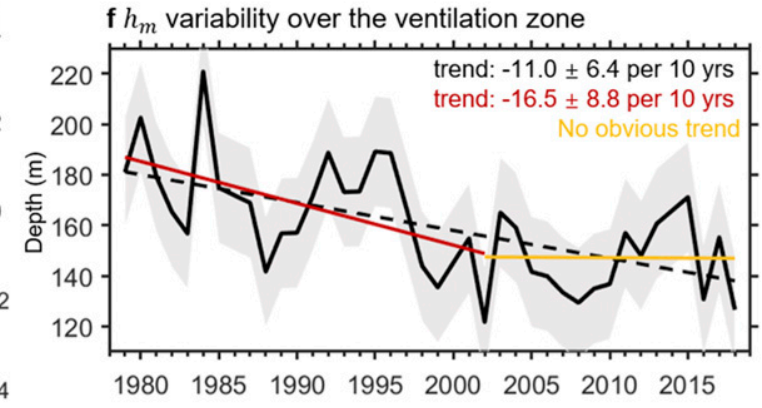

FIG. 10. (a) Latitude-depth sections of winter (January-March) mean field of temperature (contours; ${ }^{\circ} \mathrm{C}$ ) and its trend (color; $\times 10^{-2}{ }^{\circ} \mathrm{C} \mathrm{yr}^{-1}$ ) averaged between $142^{\circ}$ and $165^{\circ} \mathrm{E}$ for $1979-2002$. White line indicates the mean $h_{m}$ in winter during $1979-2002$ along $150^{\circ} \mathrm{E}$. (b) As in (a), but for the temperature vertical gradient trend (color; $\times 10^{-4}{ }^{\circ} \mathrm{C} \mathrm{m}^{-1} \mathrm{yr}^{-1}$ ). Notice that the negative value of the temperature vertical gradient trend indicates the enhanced temperature vertical gradient and vice versa. (c), (d) As in (a) and (b), but for the period during 2002-18. (e) Time series of the ocean stratification intensity within $h_{m}\left(\times 10^{-2}{ }^{\circ} \mathrm{C} \mathrm{m}^{-1}\right)$ averaged over the ventilation zone and its trend (dashed black line is for 1979-2018, red line is for 1979-2002, and yellow line is for 2002-18). The shaded error bands denote one standard deviation of annual variability. (f) As in (e), but for the mean $h_{m}$ variability (m; black line) averaged over the mode water ventilation zone. The data analyzed here are from Ishii data. 

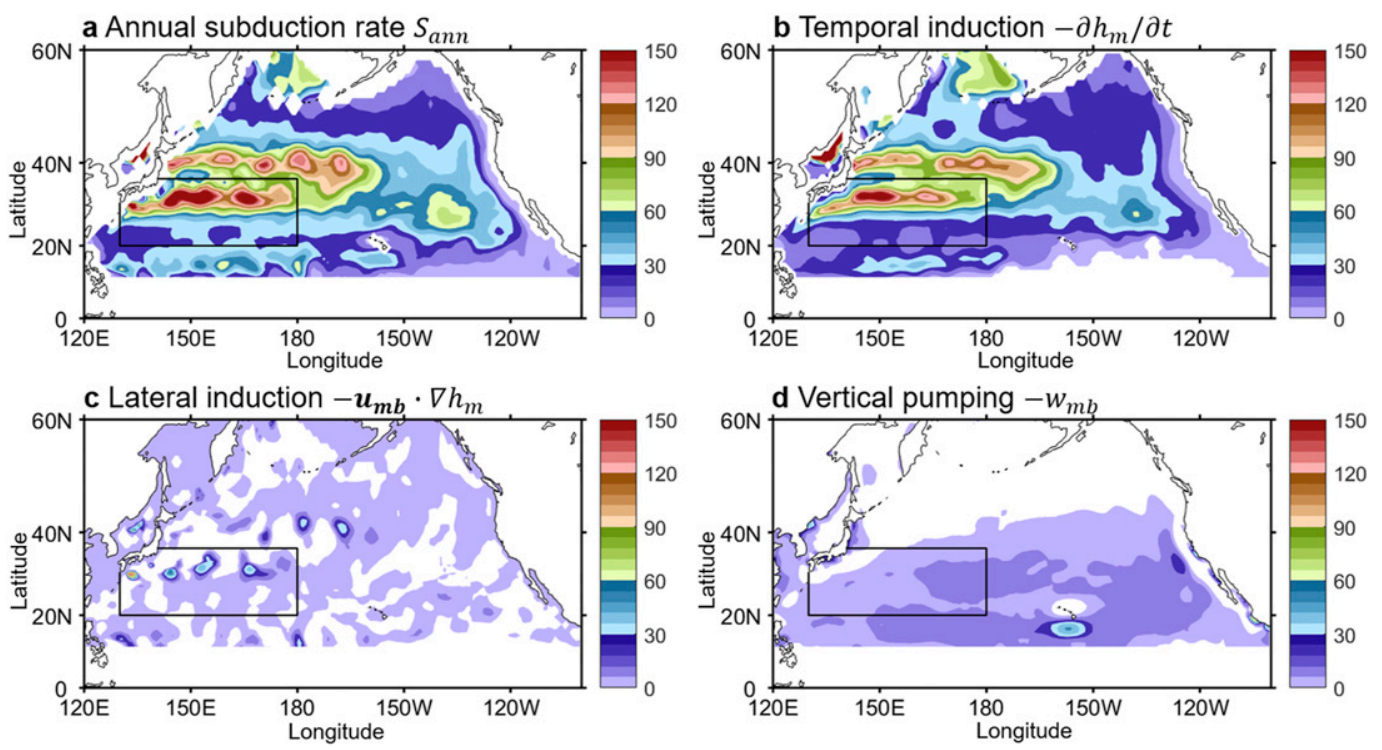

FIG. 11. (a) Climatological annual mean subduction rate $\left(\mathrm{m} \mathrm{yr}^{-1}\right)$ and its components due to (b) temporal induction $-\partial h_{m} / \partial t$, (c) lateral induction $-\mathbf{u}_{\mathrm{mb}} \cdot \nabla h_{m}$, and (d) vertical pumping $-w_{\mathrm{mb}}$ in the North Pacific Ocean for the period 1979-2018. The black box in the figures indicates the STMW formation and subduction area $\left(130^{\circ} \mathrm{E}-180^{\circ}, 20^{\circ}-37^{\circ} \mathrm{N}\right)$.

long-term changes (Fig. 12b). The lateral induction term produced patches of large positive and negative anomalies (Fig. 12c) along the KE frontal region, while the contribution from the vertical pumping was negligible (Fig. 12d).

Integrating the $S_{\text {ann }}$ over the mode water ventilation zone at the surface yielded a total annual subduction rate (total $\left.S_{\text {ann }}\right)$ with units in Sverdrups ( $\mathrm{Sv} ; 1 \mathrm{~Sv} \equiv 10^{6} \mathrm{~m}^{3} \mathrm{~s}^{-1}$ ). The year-to-year variability of the total $S_{\text {ann }}$ showed that the production of the STMW has trended downward during the past four decades (Fig. 13a). The overall rate of reduction was $-0.19 \pm 0.11 \mathrm{~Sv}$ decade $^{-1}$, amounting to a reduction of $0.76 \mathrm{~Sv}(63 \%)$ in the total $S_{\text {ann }}$ during 1979-2018. It is evident that most of the reduction in the total $S_{\text {ann }}$ occurred before $2002\left(-0.28 \pm 0.16 \mathrm{~Sv}\right.$ decade $\left.^{-1}\right)$. The decadal differences in the rate of change are similar to those found in the poleward shift of the surface KE front, the contraction of the ventilation zone and increase of the upper-layer stratification over the STMW formation area. Contribution from the three integral terms in Eq. (2) suggests that the decreasing trend of the total $S_{\text {ann }}$ was induced primarily by the decreasing trend of the temporal induction $(91 \%)$ and secondarily by the vertical pumping $(8 \%)$, with little contribution from the lateral induction (Figs. 13a,b). Previous studies have shown that the temporal induction term was the leading contribution on annual, interannual and decadal variation (Da Costa et al. 2005; Chen et al. 2010; Xu et al. 2014). The reduction of the temporal induction term was attributable to both the contraction of the ventilation zone and a shoaling of the $h_{m}$ [Eq. (2)].

The change in the surface area of the STMW ventilation zone averaged over the mode water formation area are shown in Fig. 13c. It can be seen that the temporal induction (red line in Fig. 13b) varied in coherence with both the ventilation zone (Fig. 13c) and $h_{m}$ (Fig. 10f) over the entire period. As discussed in previous subsections, decadal behaviors of the KE front shift differ before and after 2002. Similar pattern is also observed in the subduction rate as illustrated in spatial distributions of the total $S_{\text {ann }}$ and the temporal induction term (Fig. 14). Before 2002, both showed significant decreasing trends (Figs. 14a,c, differences between 1979-83 and 1998-2002), while there were no obvious changes after 2002 (Figs. 14b,d; differences between 2002-06 and 2014-18).

The relative importance of the ventilation zone contraction and $h_{m}$ shoaling on the decrease of temporal induction was further examined, following Yu et al. (2018). We first fixed the $\partial h_{m} / \partial t$ by using the climatological monthly mean at each grid, and then integrated it over the varied ventilation zone for one year, i.e., $-\int_{T_{\mathrm{se}}}^{T_{\mathrm{ef}}^{\mathrm{ef}}}\left[\iint\left(\partial \overline{h_{m}} / \partial t\right) d A\right] d t$. The results showed that the decreasing trend of the temporal induction, which was only caused by the contracted ventilation zone, was $-0.084 \pm$ $0.062 \mathrm{~Sv}_{\mathrm{decade}}{ }^{-1}$, accounting for $\sim 50 \%$ of the total temporal induction trend $\left(-0.17 \pm 0.07 \mathrm{~Sv}\right.$ decade $\left.^{-1}\right)$. That is to say, the contraction of the ventilation zone and the shoaling of the $h_{m}$ had roughly equal contributions to downward-trended temporal induction.

\section{Summary and discussion}

Two objectives were reported in this study: the long-term shift trend of the KE front and its related variation of the STMW formation during 1979-2018. The examination of a suite of datasets and definitions of the KE showed that the surface-to-subsurface structure of the KE front (averaged over $142^{\circ}-165^{\circ} \mathrm{E}$ ) has shifted poleward at a rate of $\sim 0.23^{\circ} \pm$ $0.16^{\circ}$ decade $^{-1}$. The long-term trend of the poleward shift of the KE front showed two distinct behaviors before and after 2002. Before 2002, the surface KE front moved northward 

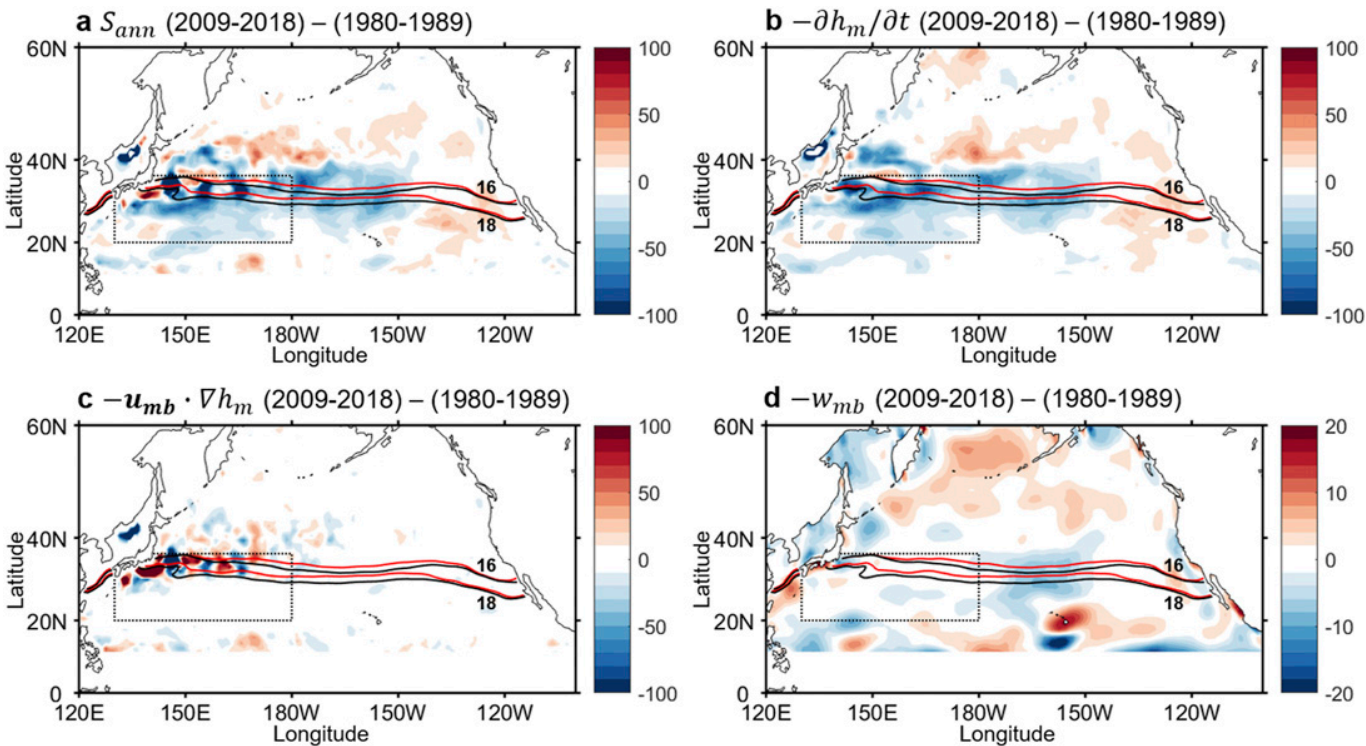

FIG. 12. (a) Decadal changes of the annual mean subduction rate and its components due to (b) temporal induction $-\partial h_{m} / \partial t$, (c) lateral induction $-\mathbf{u}_{\mathrm{mb}} \cdot \nabla h_{m}$, and (d) vertical pumping $-w_{\mathrm{mb}}$ in the North Pacific Ocean between 1980-89 and 2009-18 (latter minus former; $\mathrm{m} \mathrm{yr}^{-1}$ ). The red and black contours in the figures indicate the winter-mean (January-March) $16^{\circ}$ and $18^{\circ} \mathrm{C}$ isotherms during 2009-18 and 1980-89, respectively. The black box in the figures indicates the STMW formation and subduction area $\left(130^{\circ} \mathrm{E}-180^{\circ}, 20^{\circ}-37^{\circ} \mathrm{N}\right)$. Notice that the color bar range of $(d)$ is $[-20,20]$ which is 5 times smaller than (a)-(c).

with a faster rate than the subsurface KE front. After 2002, the surface KE front showed no obvious trend, but the subsurface $\mathrm{KE}$ front continued to move northward. Along with the poleward shift of the KE front, the STMW ventilation zone has contracted and moved northward with shoaling of the $h_{m}$ before 2002 when the KE front moved northward. The subduction rate of the STMW was reduced by $0.76 \mathrm{~Sv}(63 \%)$ in the past four decades, most of which occurred before 2002. Of the three components affecting the total subduction rate, the temporal induction $\left(-\partial h_{m} / \partial t\right)$ was dominant, accounting for $91 \%$ of the rate reduction, while the vertical pumping $\left(-w_{\mathrm{mb}}\right)$ amounted to $8 \%$ and the lateral induction $\left(-\mathbf{u}_{\mathrm{mb}} \cdot \nabla h_{m}\right)$ was insignificant.

The temporal induction is found to have weakened in responding to both the contracted ventilation zone and the shallowed $h_{m}$ (Figs. 13 and 10f), and the change was a dominant contributor to the reduction of the total $S_{\text {ann }}$. The shoaling of the $h_{m}$ represents an upward buoyancy flux or a conversion between potential energy and turbulent kinetic energy, driven by the surface wind stirring and/or surface convection (e.g., Niiler 1975), or by surface advection (Wu et al. 2020a,b). The enhanced upper-ocean stratification shown in Fig. 10b before 2002 shallowed $h_{m}$, as a strong upper-ocean stratification is unfavorable to the mixed layer development (e.g., Qiu and Chen 2006; Sugimoto and Kako 2016). On a broader scale, surface WSC also affects $h_{m}$, with a shallow $h_{m}$ corresponding to positive WSC (Fig. 4c in Wu et al. 2019). Compared to the temporal induction $\left(-\partial h_{m} / \partial t\right)$, the lateral induction $\left(-\mathbf{u}_{\mathrm{mb}} \cdot \nabla h_{m}\right)$ showed patchy structures alternating between large positive and negative anomalies (Fig. 12c). These patches may be caused by mesoscale activities, such as eddies or large meanders of the KE current and had negligible effect on the integration of the lateral induction in the analysis region (black box in Fig. 12) due to the cancellation of the "negative-positive" patches.

The KE front in this analysis was searched between $142^{\circ}$ and $165^{\circ} \mathrm{E}$, including the upstream $\left(142^{\circ}-153^{\circ} \mathrm{E}\right)$ and downstream $\left(153^{\circ}-165^{\circ} \mathrm{E}\right) \mathrm{KE}$ fronts (e.g., Yang et al. 2018). Most previous studies have mainly focused on the upstream KE front variability. To compare with these studies, we separated the $\mathrm{KE}$ front into upstream $\left(142^{\circ}-153^{\circ} \mathrm{E}\right)$ and downstream $\left(153^{\circ}-165^{\circ} \mathrm{E}\right)$ and recomputed their meridional movement (Fig. 15). The results show that the upstream KE front exhibited clear interannual-to-decadal variability but no clear poleward shift trend from the surface to the subsurface (Figs. 15a-c), consistent with the studies by Seo et al. (2014) and Kim et al. (2020). By contrast, the downstream KE front showed strong northward shift trend, at a rate of $0.40^{\circ} \pm 0.29^{\circ}$, $0.38^{\circ} \pm 0.26^{\circ}$, and $0.43^{\circ} \pm 0.32^{\circ}$ decade $^{-1}$ for the surface, $200-\mathrm{m}$, and $300-\mathrm{m}$ depth, respectively. The overall averaged trend is $0.41^{\circ} \pm 0.29^{\circ}$ decade $^{-1}$ for the movement of the vertical downstream KE front (Figs. 15d-f). Hence, the poleward shift of the whole KE front mainly originated from the downstream $\mathrm{KE}$ front. The rate of the shift of the downstream KE front is on the order of $0.4^{\circ}$ decade $^{-1}$ during the past four decades, which is consistent with the HC expansion trend of approximately $0.5^{\circ}-1.0^{\circ}$ decade $^{-1}$ (Lucas et al. 2014). In addition, the surface downstream KE front moved poleward faster before 2002 than that after 2002 (Fig. 15d), while the subsurface downstream KE front showed steady poleward shift during the entire analysis period (Figs. 15e,f). It is interesting that the KE fronts exhibited different poleward shift before and after 2002 , 

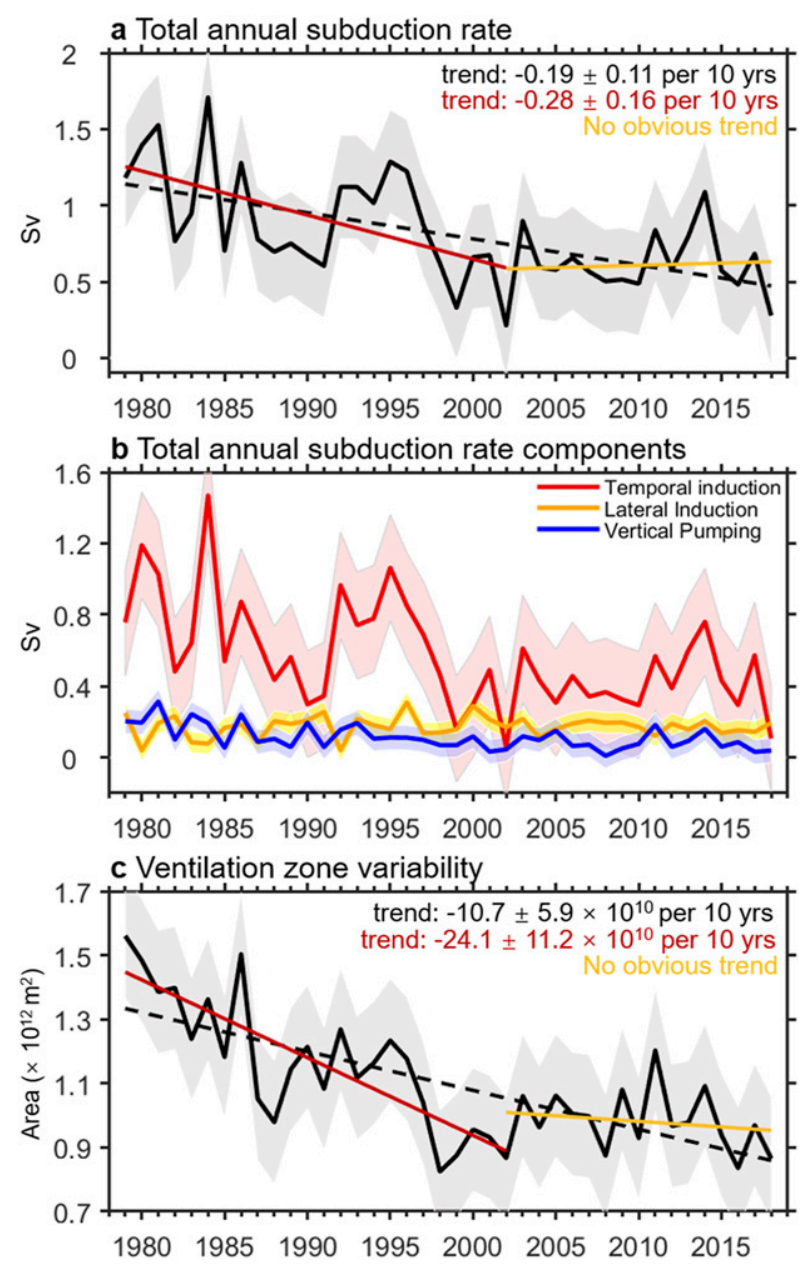

FIG. 13. (a) Time series of total annual subduction rate (total $S_{\text {ann }} ; \mathrm{Sv}$ ) and its trend. (b) Time series of the contribution of temporal induction $-\partial h_{m} / \partial t$ (red), lateral induction $-\mathbf{u}_{\mathrm{mb}} \cdot \nabla h_{m}$ (yellow), and vertical pumping $-w_{\mathrm{mb}}$ (blue) on the total $S_{\text {ann }}$ during the period of 1979-2018. (c) The area integral of the STMW ventilation zone in temperature coordinate $\left(\times 10^{12} \mathrm{~m}^{2}\right)$ and its trend. After detrending, the correlation coefficient between temporal induction and ventilation zone variability is 0.76 , between temporal induction and $h_{m}$ variability (Fig. 10f) is 0.87 , and both are statistically significant above the $95 \%$ confidence level. The shaded error bands denote one standard deviation of annual variability for each variable. In (a), (c), and (d), the dashed black line, red line, and yellow line indicate the trend for 1979-2018, 19792002, and 2002-18, respectively.

which may be due to the natural decadal to multidecadal variability (Yang et al. 2020b). The 1979-2002 period is so-called "fast warming," while the following decade is the global warming "hiatus" (Deser et al. 2017). Consequently, the increase of SST had a faster pace during 1979-2002 but slowed down during 2002-18. The northward shift of SST isotherms and the surface $\mathrm{KE}$ front exhibited a similar change during the two periods. The reason that the subsurface KE front was relatively stable and had no obvious changes in the pace of the shift before and after 2002 (Figs. 7 and 15) is perhaps due to the fact that the subsurface is less directly affected by the surface thermal forcing. Further study is needed to gain an understanding of the dynamical processes governing the surface and subsurface interactions.

We have also identified the difference in the long-term shift trends between the upstream and downstream KE front. The downstream KE front showed a robust poleward shift, while the upstream KE front was stable and showed little northward movement. The KE front is located in the northern edge of the subtropical gyre and can be represented by the Sverdrup streamline. The Sverdrup balance relates the steady-state large-scale ocean circulation to the surface WSC forcing (Sverdrup 1947). Hautala et al. (1994) concluded that the Pacific subtropical gyre circulation is well explained by the Sverdrup transport, based on the hydrographic data along the $24^{\circ} \mathrm{N}$ section from the eastern boundary up to $137^{\circ} \mathrm{E}$. The Sverdrup streamfunction $\psi$ can be derived by zonal integration of WSC westward from the eastern boundary along each latitude as follows:

$$
\psi(x)=-\frac{1}{\rho_{0} \beta} \int_{x_{e}}^{x} \operatorname{curl} \tau d x+\psi\left(x_{e}\right),
$$

where $\rho_{0}$ is a reference seawater density, and $\beta$ the $y$ derivative of the Coriolis parameter $f$. The path of the integration is taken zonally from the eastern boundary $x_{e}$ to $x$, and $\psi\left(x_{e}\right)$ is the boundary value at the eastern coast and is set to zero. The relationship between the zero WSC line and the zero Sverdrup streamline can be found in Fig. 5b in Wu et al. (2019). Following the Sverdrup theory, the upstream and downstream $\mathrm{KE}$ fronts should both move poleward in the past 40 years under the observed expansion of the HC (or the zero-WSC line, Fig. 4c in Wu et al. 2019). Hence, the question remained is why the upstream KE front exhibited no poleward shift. One possible candidate is the topography (colored in Fig. 1), which anchored the upstream KE front. As discussed in Hurlburt et al. (1996), the bottom topography, i.e., the sea mounts east of the trench $\left(143^{\circ}-144^{\circ} \mathrm{E}\right)$ and the abyssal plain to the further east, may have a strong influence on the KE currents owing to the conservation of potential vorticity. Consequently, the upstream KE front would be anchored to bottom with no long-term shift trend, similar to the case of the western OE front (Mitsudera et al. 2018; Wu et al. 2018).

In addition to the effect of local bottom topography, we found that the longitudinal asymmetry in temperature anomalies may also contribute to the difference in the shift trends between the upstream and downstream KE fronts. As indicated by the colored background in Fig. 8a, the surface warm anomalies were larger in the east (downstream KE front) than those in the west (upstream KE front). Wu et al. (2019) argued that the local Ekman heat transport anomaly due to the wind field changes $\left(v^{\prime} \overline{\nabla S S T}\right)$ could be one of the contributors to induce this longitudinal asymmetry in temperature anomalies and keep the western OE front stable. This is similar to the western KE front, while the contribution from the Ekman heat transport to the KE front shift should be small, because of the deep $h_{m}$ in winter and also the weak SST meridional gradient compared to that in OE frontal area. 

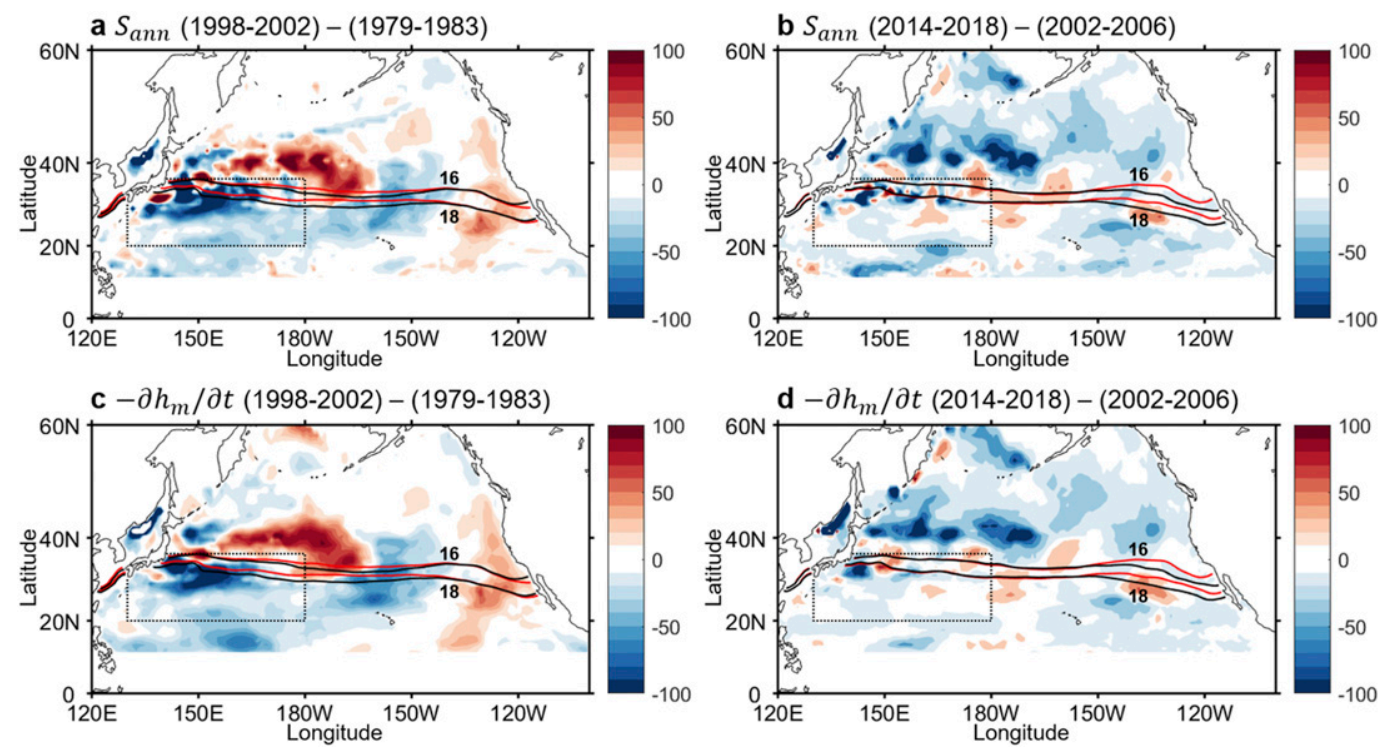

FIG. 14. (a) Annual mean subduction rate changes between 1979-83 and 1998-2002 (latter minus former; $\mathrm{m} \mathrm{yr}^{-1}$ ). (b) As in (a), but for the changes between 2002-06 and 2014-18 (latter minus former; $\mathrm{m} \mathrm{yr}^{-1}$ ). (c),(d) As in (a) and (b), but for temporal induction $-\partial h_{m} / \partial t$. The red and black contours indicate the winter-mean (January-March) $16^{\circ}$ and $18^{\circ} \mathrm{C}$ isotherms during 1998-2002 and 1979-83 in (a) and (c), and during 2014-18 and 2002-06 in (b) and (d), respectively. The black box in the panels indicates the STMW formation and subduction area $\left(130^{\circ} \mathrm{E}-180^{\circ}, 20^{\circ}-37^{\circ} \mathrm{N}\right)$.

Yang et al. (2020a) attributed the HC expansion as well as the poleward shift of the North Pacific subtropical gyre to the global warming in the recent 40 years, although they pointed out that the natural climate variability, e.g., PDO and Atlantic multidecadal oscillation (AMO), could also be a factor. On the other hand, Wu et al. (2019) suggested that the easterly wind anomalies in the subtropical and subpolar North Pacific (indicating poleward expansion of the $\mathrm{HC}$ ) in the recent decades were induced primarily by the AMO and second by the PDO. The mean temperature of the STMW had a strong correlation with the AMO (Wu et al. 2020a), and hence, the fast warming trend in recent 40 years should come from both the AMO phase changes (negative to positive) and global warming (Sugimoto et al. 2017). The relative contribution of global warming and the natural variability to the $\mathrm{HC}$ and $\mathrm{KE}$ expansion and the resultant reduction in the STMW formation in the recent decades would be an interesting topic for further study.

It should be pointed out that the relationship between the KE front position and the STMW formation is different on different time scales. As discussed by previous studies (e.g., Oka et al. 2015), on the interannual to decadal time scale, eddy activities are weak with stronger STMW formation when the $\mathrm{KE}$ front is in its northern position (stable state). However, in this study, we found that the northward shift of the KE front resulted in a reduction of the STMW subduction rate. The disparity reflects the competition of two mechanisms, the eddy effects versus large-scale ocean dynamics. Because of the coarse resolution of the observational datasets, we were not able to consider the role of eddies in this study. Nonetheless, our results were consistent with Liu and $\mathrm{Hu}$ (2007) that the weakened westerlies in the midlatitudes reduced the subduction rate and the STMW volume, suggesting that the eddy impact may not be the leading factor in decadal to multidecadal variability. As discussed in section $3 c$, the impact of mesoscale variability on the total $S_{\text {ann }}$ were small due to the cancellation effect on the area integration. Further work is needed to provide a systematic analysis of the interaction among the eddy activities, the frontal variation and the evolution of the mode water.

Our study may have broad environmental and societal impacts. On the one hand, the poleward shift of the KE front could change the overlaying atmospheric circulation and storm track (Primeau and Cessi 2001; Wang et al. 2017), as well as the rainband (Minobe et al. 2010). This would further induce change to the local climate through complex interaction between the atmosphere and the ocean (e.g., Minobe et al. 2008). On the other hand, the STMW formation region constitutes one of the largest ocean carbon sinks for the atmospheric $\mathrm{CO}_{2}$ in the Northern Hemisphere (Takahashi et al. 2009). The reduction of the STMW subduction rate would reduce the ocean carbon absorption and would further amplify the global warming. The advection of the STMW could also influence the nutrient concentration in the downstream region near the western boundary (Oka et al. 2015). Consequently, changes of the STMW formation would affect the ocean biogeochemical cycle and fishery. Last but not least, it is reported that the STMW is one of the key factors that controls the subtropical gyre (Kobashi et al. 2006). For example, the reduced mode water formation could weaken the subtropical counter current (Xu et al. 2011, 2012) and vice versa (Zhang et al. 2019), and the variability of subtropical counter current would affect the SST in the subtropical frontal region which in turn feedbacks to the local precipitation and climate (Xie et al. 2011). In summary, the poleward shift of the KE front and reduction of the 

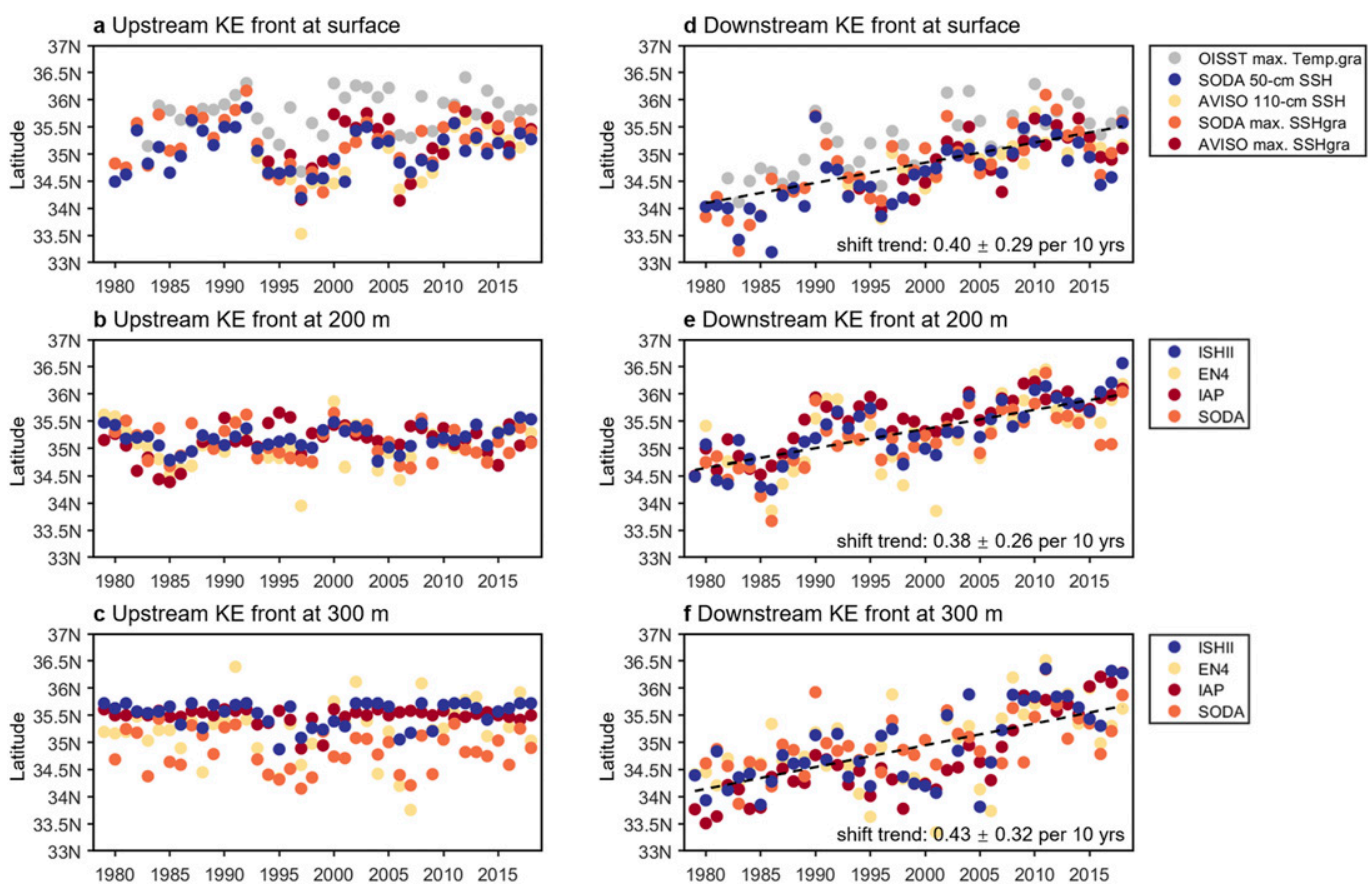

FIG. 15. Time series of the winter mean (January-March) meridional shift of the upstream KE front position averaged between $142^{\circ}$ and $153^{\circ} \mathrm{E}$ at (a) surface, (b) $200 \mathrm{~m}$, and (c) $300 \mathrm{~m}$ based on different datasets and methods as indicated by the legends. (d)-(f) As in (a)-(c), but for the downstream KE front averaged between $153^{\circ}$ and $165^{\circ} \mathrm{E}$ and its mean trend (dashed line). Please see the text and Table 1 for more details.

STMW formation have potentially important implications in many fronts and should be further researched.

Acknowledgments. This study benefited from discussions with Young-Oh Kwon. The anonymous reviewers provided useful and constructive comments in revising the manuscript. The SODA dataset of version 3.4.2 used in this research is publicly available (http://www.soda.umd.edu/), the Ishii data from https://climate.mri-jma.go.jp/pub/, the EN4 data from https://www.metoffice.gov.uk/hadobs/en4/, the IAP data from http://159.226.119.60/cheng/, the NOAA OISSTv2 data from ftp:// eclipse.ncdc.noaa.gov/, the ERA-Interim wind stress data from http://apps.ecmwf.int/ and the AVISO SSH data from http://www.aviso.oceanobs.com. Xiaopei Lin is supported by the National Natural Science Foundation of China (41925025 and 92058203) and China's national key research and development projects (2016YFA0601803). Baolan $\mathrm{Wu}$ is supported by the China Scholarship Council (201806330010). Lisan $\mathrm{Yu}$ thanks NOAA for support for her study on climate change and variability.

\section{REFERENCES}

Alexander, M. A., C. Deser, and M. S. Timlin, 1999: The reemergence of SST anomalies in the North Pacific Ocean. J. Climate, 12, 2419-2433, https://doi.org/10.1175/1520-0442(1999) $012<2419$ :TROSAI $>2.0 . \mathrm{CO} ; 2$.

Archer, C. L., and K. Caldeira, 2008: Historical trends in the jet streams. Geophys. Res. Lett., 35, L08803, https://doi.org/ 10.1029/2008GL033614.
Bates, N. R., A. C. Pequignet, R. J. Johnson, and N. Gruber, 2002: A short-term sink for atmospheric $\mathrm{CO}_{2}$ in subtropical mode water of the North Atlantic Ocean. Nature, 420, 489-493, https://doi.org/10.1038/nature01253.

Bretherton, C. S., M. Widmann, V. P. Dymnidov, J. M. Wallace, and I. Blade, 1999: The effective number of spatial degrees of freedom of a time-varying field. J. Climate, 12, 1990-2009, https://doi.org/10.1175/1520-0442(1999)012<1990:TENOSD> 2.0.CO;2.

Carton, J. A., G. A. Chepurin, and L. Chen, 2018a: SODA3: A new ocean climate reanalysis. J. Climate, 31, 6967-6983, https:// doi.org/10.1175/JCLI-D-18-0149.1.

,,--- , and S. A. Grodsky, 2018b: Improved global net surface heat flux. J. Geophys. Res. Oceans, 123, 3144-3163, https://doi.org/10.1002/2017JC013137.

Cerovečki, I., and D. Giglio, 2016: North Pacific subtropical mode water volume decrease in 2006-09 estimated from Argo observations: Influence of surface formation and basin-scale oceanic variability. J. Climate, 29, 2177-2199, https://doi.org/ 10.1175/JCLI-D-15-0179.1.

Chen, G., J. Lu, and D. M. Frierson, 2008: Phase speed spectra and the latitude of surface westerlies: Interannual variability and global warming trend. J. Climate, 21, 5942-5959, https:// doi.org/10.1175/2008JCLI2306.1.

Chen, J., T. Qu, Y. N. Sasaki, and N. Schneider, 2010: Anticorrelated variability in subduction rate of the western and eastern North Pacific Oceans identified by an eddy-resolving ocean GCM. Geophys. Res. Lett., 37, L23608, https://doi.org/ 10.1029/2010GL045239.

Chen, S., 2008: The Kuroshio Extension Front from satellite sea surface temperature measurements. J. Oceanogr., 64, 891-897, https://doi.org/10.1007/s10872-008-0073-6. 
K. Wei, W. Chen, and L. Song, 2014: Regional changes in the annual mean Hadley circulation in recent decades. J. Geophys. Res. Atmos., 119, 7815-7832, https://doi.org/10.1002/2014JD021540.

Chen, X., X. Zhang, J. A. Church, C. S. Watson, M. A. King, D. Monselesan, B. Legresy, and C. Harig, 2017: The increasing rate of global mean sea-level rise during 1993-2014. Nat. Climate Change, 7, 492-497, https://doi.org/10.1038/ NCLIMATE3325.

Cheng, L., K. Trenberth, J. Fasullo, T. Boyer, J. Abraham, and J. Zhu, 2017: Improved estimates of ocean heat content from 1960 to 2015. Sci. Adv., 3, e1601545, https://doi.org/10.1126/ sciadv.1601545.

Cushman-Roisin, B., 1987: Subduction. Dynamics of the Oceanic Surface Mixed Layer, P. Muller and D. Henderson, Eds., Hawaii Institute of Geophysics Special, 181-196.

Da Costa, M. V., H. Mercier, and A. M. Treguier, 2005: Efects of the mixed layer time variability on kinematic subduction rate diagnostics. J. Phys. Oceanogr., 35, 427-443, https://doi.org/ 10.1175/JPO2693.1.

Dee, D. P., and Coauthors, 2011: The ERA-Interim reanalysis: Configuration and performance of the data assimilation system. Quart. J. Roy. Meteor. Soc., 137, 553-597, https://doi.org/ 10.1002/qj.828.

Deser, C., R. Guo, and F. Lehner, 2017: The relative contributions of tropical Pacific sea surface temperatures and atmospheric internal variability to the recent global warming hiatus. Geophys. Res. Lett., 44, 7945-7954, https://doi.org/10.1002/ 2017 GL074273.

Ducet, N., P. Y. Le Traon, and G. Reverdin, 2000: Global highresolution mapping of ocean circulation from TOPEX/Poseidon and ERS-1 and -2. J. Geophys. Res., 105, 19477-19498, https:// doi.org/10.1029/2000JC900063.

Frankignoul, C., N. Sennéchael, Y.-O. Kwon, and M. A. Alexander, 2011: Influence of the meridional shifts of the Kuroshio and the Oyashio Extensions on the atmospheric circulation. J. Climate, 24, 762-777, https://doi.org/10.1175/2010JCLI3731.1.

Good, S. A., M. J. Martin, and N. A. Rayner, 2013: EN4: Quality controlled ocean temperature and salinity profiles and monthly objective analyses with uncertainty estimates. J. Geophys. Res. Oceans, 118, 6704-6716, https://doi.org/ 10.1002/2013JC009067.

Hanawa, K., 1987: Interannual variations in the wintertime outcrop area of subtropical mode water in the western North Pacific Ocean. Atmos.-Ocean, 25, 358-374, https://doi.org/10.1080/ 07055900.1987.9649280.

Hautala, S. L., and D. H. Roemmich, 1998: Subtropical mode water in the northeast Pacific basin. J. Geophys. Res., 103, 13 05513 066, https://doi.org/10.1029/98JC01015.

- — - , and W. J. Schmitz Jr., 1994: Is the North Pacific in Sverdrup balance along $24^{\circ}$ N? J. Geophys. Res., 99, $16041-$ 16 052, https://doi.org/10.1029/94JC01084.

Hudson, R. D., M. F. Andrade, M. B. Follette, and A. D. Frolov, 2006: The total ozone field separated into meteorological regimes-Part II: Northern Hemisphere mid-latitude total ozone trends. Atmos. Chem. Phys., 6, 5183-5191, https://doi.org/ 10.5194/acp-6-5183-2006.

Hurlburt, H. E., A. J. Wallcraft, W. J. Schmitz, P. J. Hogan, and E. J. Metzger, 1996: Dynamics of the Kuroshio/Oyashio current system using eddy-resolving models of the North Pacific Ocean. J. Geophys. Res., 101, 941-976, https://doi.org/10.1029/ 95JC01674.

Ishii, M., Y. Fukuda, S. Hirahara, S. Yasui, T. Suzuki, and K. Sato, 2017: Accuracy of global ocean heat content estimation expected from present observational data sets. SOLA, 13, 163-167, https://doi.org/10.2151/sola.2017-030.

Johnson, G. C., S. Schmidtko, and J. M. Lyman, 2012: Relative contributions of temperature and salinity to seasonal mixed layer density changes and horizontal density gradients. J. Geophys. Res., 117, C04015, https://doi.org/10.1029/ 2011JC007651.

Joyce, T. M., Y.-O. Kwon, and L. Yu, 2009: On the relationship between synoptic wintertime atmospheric variability and path shifts in the Gulf Stream and the Kuroshio Extension. J. Climate, 22, 3177-3192, https://doi.org/10.1175/ 2008JCLI2690.1.

Kida, S., and Coauthors, 2015: Oceanic fronts and jets around Japan: A review. J. Oceanogr., 71, 469-497, https://doi.org/ 10.1007/s10872-015-0283-7.

Kim, S.-Y., and Coauthors, 2020: Late-1980s regime shift in the formation of the North Pacific subtropical mode water. J. Geophys. Res. Oceans, 125, e2019JC015700, https://doi.org/ 10.1029/2019JC015700.

Kobashi, F., H. Mitsudera, and S.-P. Xie, 2006: Three subtropical fronts in the North Pacific: Observational evidence for mode water-induced subsurface frontogenesis. J. Geophys. Res., 111, C09033, https://doi.org/10.1029/2006JC003479.

Liu, L., and R. X. Huang, 2012: The global subduction/obduction rates, their interannual and decadal variability. J. Climate, $\mathbf{2 5}$, 1096-1115, https://doi.org/10.1175/2011JCLI4228.1.

Liu, Q., and H. Hu, 2007: A subsurface pathway for low potential vorticity transport from the central North Pacific toward Taiwan Island. Geophys. Res. Lett., 34, L12710, https://doi.org/ 10.1029/2007GL029510.

Lu, J., G. A. Vecchi, and T. Reichler, 2007: Expansion of the Hadley cell under global warming. Geophys. Res. Lett., 34, L06805, https://doi.org/10.1029/2006GL028443.

Lucas, C., B. Timbal, and H. Nguyen, 2014: The expanding tropics: A critical assessment of the observational and modelling studies. Wiley Interdiscip. Rev.: Climate Change, 5, 89-112, https://doi.org/10.1002/wcc.251.

Masuzawa, J., 1969: Subtropical mode water. Deep-Sea Res. Oceanogr. Abstr., 16, 463-472, https://doi.org/10.1016/00117471(69)90034-5.

Mathew, S. S., K. K. Kumar, and K. V. Subrahmanyam, 2016: Hadley cell dynamics in Japanese reanalysis-55 dataset: Evaluation using other reanalysis datasets and global radiosonde network observations. Climate Dyn., 47, 3917-3930, https://doi.org/10.1007/s00382-016-3051-5.

Minobe, S., A. Kuwano-Yoshida, N. Komori, S.-P. Xie, and R. J. Small, 2008: Influence of the Gulf Stream on the troposphere. Nature, 452, 206-209, https://doi.org/10.1038/nature06690.

_- M. Miyashita, A. Kuwano-Yoshida, H. Tokinaga, and S.-P. Xie, 2010: Atmospheric response to the Gulf Stream: Seasonal variations. J. Climate, 23, 3699-3719, https://doi.org/10.1175/ 2010JCLI3359.1.

Mitsudera, H., and Coauthors, 2018: Low ocean-floor rises regulate subpolar sea surface temperature by forming baroclinic jets. Nat. Commun., 9, 1190, https://doi.org/10.1038/s41467-01803526-z.

Mizuno, K., and W. B. White, 1983: Annual and interannual variability in the Kuroshio Current system. J. Phys. Oceanogr., 13, 1847-1867, https://doi.org/10.1175/1520-0485(1983)013<1847: AAIVIT $>2.0 . C O ; 2$.

Munk, W. H., 1950: On the wind-driven ocean circulation. J. Meteor., 7, 80-93, https://doi.org/10.1175/1520-0469(1950) 007<0080:OTWDOC $>2.0 . \mathrm{CO} ; 2$. 
Niiler, P., 1975: Deepening of the wind-mixed layer. J. Mar. Res., 33, 405-422.

Nonaka, M., H. Nakamura, Y. Tanimoto, T. Kagimoto, and H. Sasaki, 2006: Decadal variability in the Kuroshio-Oyashio Extension simulated in an eddy-resolving OGCM. J. Climate, 19, 1970-1989, https://doi.org/10.1175/JCLI3793.1.

Norris, J. R., R. J. Allen, A. T. Evan, M. D. Zelinka, C. W. O’Dell, and S. A. Klein, 2016: Evidence for climate change in the satellite cloud record. Nature, 536, 72-75, https://doi.org/ 10.1038/nature18273.

Oka, E., and B. Qiu, 2012: Progress of North Pacific mode water research in the past decade. J. Oceanogr., 68, 5-20, https:// doi.org/10.1007/s10872-011-0032-5.

,-- S. Kouketsu, K. Uehara, and T. Suga, 2012: Decadal seesaw of the central and subtropical mode water formation associated with the Kuroshio Extension variability. J. Oceanogr., 68, 355-360, https://doi.org/10.1007/s10872011-0098-0.

— , and Coauthors, 2015: Decadal variability of Subtropical Mode Water subduction and its impact on biogeochemistry. J. Oceanogr., 71, 389-400, https://doi.org/10.1007/s10872-0150300-x.

Primeau, F., and P. Cessi, 2001: Coupling between wind-driven currents and midlatitude storm tracks. J. Climate, 14, 1243-1261, https://doi.org/10.1175/1520-0442(2001)014<1243:CBWDCA > 2.0.CO;2.

Qiu, B., and R. X. Huang, 1995: Ventilation of the North Atlantic and North Pacific: Subduction versus obduction. J. Phys. Oceanogr., 25, 2374-2390, https://doi.org/10.1175/15200485(1995)025<2374:VOTNAA $>2.0$. CO;2.

— , and S. Chen, 2005: Variability of the Kuroshio Extension jet, recirculation gyre and mesoscale eddies on decadal timescales. J. Phys. Oceanogr., 35, 2090-2103, https://doi.org/10.1175/ JPO2807.1.

— , and - 2006: Decadal variability in the formation of the North Pacific Subtropical Mode Water: Oceanic versus atmospheric control. J. Phys. Oceanogr., 36, 1365-1380, https:// doi.org/10.1175/JPO2918.1.

- and — 2010: Eddy-mean flow interaction in the decadally modulating Kuroshio Extension system. Deep-Sea Res., 57, 1098-1110, https://doi.org/10.1016/j.dsr2.2008.11.036.

,,-- N. Schneider, and B. Taguchi, 2014: A coupled decadal prediction of the dynamic state of the Kuroshio Extension system. J. Climate, 27, 1751-1764, https://doi.org/10.1175/ JCLI-D-13-00318.1.

,-- , and — 2017: Dynamical links between the decadal variability of the Oyashio and Kuroshio Extensions. J. Climate, 30, 9591-9605, https://doi.org/10.1175/JCLI-D-17-0397.1.

Qu, T., S.-P. Xie, H. Mitsudera, and A. Ishida, 2002: Subduction of the North Pacific mode waters in a global high-resolution GCM. J. Phys. Oceanogr., 32, 746-763, https://doi.org/10.1175/ 1520-0485(2002)032<0746:SOTNPM $>2.0$.CO;2.

Reichler, T., 2009: Changes in the atmospheric circulation as an indicator of climate change. Climate Change: Observed Impacts on Planet Earth, T. M. Letcher Eds., Elsevier, 145-164.

Reynolds, R. W., T. M. Smith, C. Liu, D. B. Chelton, K. S. Casey, and M. G. Schlax, 2007: Daily high-resolution-blended analyses for sea surface temperature. J. Climate, 20, 5473-5496, https://doi.org/10.1175/2007JCLI1824.1.

Sasaki, Y. N., and S. Minobe, 2015: Climatological mean features and interannual to decadal variability of ring formations in the Kuroshio Extension region. J. Oceanogr., 71, 499-509, https:// doi.org/10.1007/s10872-014-0270-4.
Seidel, D. J., Q. Fu, W. J. Randel, and T. J. Reichler, 2008: Widening of the tropical belt in a changing climate. Nat. Geosci., 1, 21-24, https://doi.org/10.1038/ngeo.2007.38.

Seo, Y., S. Sugimoto, and K. Hanawa, 2014: Long-term variations of the Kuroshio Extension path in winter: Meridional movement and path state change. J. Climate, 27, 5929-5940, https:// doi.org/10.1175/JCLI-D-13-00641.1.

Stommel, H. 1948: The westward intensification of wind-driven ocean currents. Eos, Trans. Amer. Geophys. Union, 29, 202206, https://doi.org/10.1029/TR029i002p00202.

Suga, T., Y. Takei, and K. Hanawa, 1997: Thermostad distribution in the North Pacific subtropical gyre: The central mode water and the Subtropical Mode Water. J. Phys. Oceanogr., 27, 140-152, https://doi.org/10.1175/1520-0485(1997)027<0140: TDITNP $>2.0 . \mathrm{CO} ; 2$.

Sugimoto, S., and K. Hanawa, 2005: Remote reemergence areas of winter sea surface temperature anomalies in the North Pacific. Geophys. Res. Lett., 32, L01606, https://doi.org/ 10.1029/2004GL021410.

_, and —_, 2010: Impact of Aleutian Low activity on the STMW formation in the Kuroshio recirculation gyre region. Geophys. Res. Lett., 37, L03606, https://doi.org/10.1029/ 2009GL041795.

_ , and S. I. Kako, 2016: Decadal variation in winter mixed layer depth south of the Kuroshio Extension and its influence on winter mixed layer temperature. J. Climate, 29, 1237-1252, https://doi.org/10.1175/JCLI-D-15-0206.1.

—, K. Hanawa, T. Watanabe, T. Suga, and S.-P. Xie, 2017: Enhanced warming of the subtropical mode water in the North Pacific and North Atlantic. Nat. Climate Change, 7, 656-658, https://doi.org/10.1038/nclimate3371.

Sverdrup, H. U., 1947: Wind-driven currents in a baroclinic ocean: With application to the equatorial currents in the eastern Pacific. Proc. Natl. Acad. Sci. USA, 33, 318-326, https:// doi.org/10.1073/pnas.33.11.318.

Takahashi, T., and Coauthors, 2009: Climatological mean and decadal change in surface ocean $\mathrm{pCO}_{2}$ and net sea-air $\mathrm{CO}_{2}$ flux over the global oceans. Deep-Sea Res. I, 56, 2075-2076, https:// doi.org/10.1016/j.dsr.2009.07.007.

Talley, L. D., 1999: Some aspects of ocean heat transport by the shallow, intermediate and deep overturning circulation. Mechanisms of Global Climate Change at Millennial Time Scales, Geophys. Monogr., Vol. 112, Amer. Geophys. Union, 22 pp., https://doi.org/10.1029/GM112p0001.

Wang, J., H. M. Kim, and E. K. M. Chang, 2017: Changes in Northern Hemisphere winter storm tracks under the background of Arctic amplification. J. Climate, 30, 3705-3724, https://doi.org/10.1175/JCLI-D-16-0650.1.

Wen, Z. B., H. B. Hu, Z. Y. Song and Z. Y. Wang, 2019: Different influences of mesoscale oceanic eddies on the North Pacific subsurface low potential vorticity water mass between winter and summer. J. Geophys. Res. Oceans, 125, e2019JC015333, https://doi.org/10.1029/2019JC015333.

Williams, R. G., M. Spall, and J. C. Marshall, 1995: Does Stommel's mixed layer "demon" work? J. Phys. Oceanogr., 25, 3089-3102, https://doi.org/10.1175/1520-0485(1995)025<3089:DSMLW> 2.0.CO;2.

Wu, B., X. Lin, and B. Qiu, 2018: Meridional shift of the Oyashio Extension front in the past 36 years. Geophys. Res. Lett., $\mathbf{4 5}$, 9042-9048, https://doi.org/10.1029/2018GL078433.

- — - and — 2019: On the seasonal variability of the Oyashio Extension fronts. Climate Dyn., 53, 7011-7025, https://doi.org/10.1007/s00382-019-04972-1. 
and L. Yu, 2020a: North Pacific subtropical mode water controlled by the Atlantic Multi-Decadal Variability. Nat. Climate Change, 10, 238-243, https://doi.org/10.1038/s41558020-0692-5.

,-- , and $-2020 \mathrm{~b}$ : The decadal to multidecadal variability of mixed layer in the South of Kuroshio Extension region. J. Climate, 33, 7697-7714, https://doi.org/10.1175/ JCLI-D-20-0115.1.

Wu, L., and Coauthors, 2012: Enhanced warming over the global subtropical western boundary currents. Nat. Climate Change, 2, 161-166, https://doi.org/10.1038/nclimate1353.

Xie, S.-P., L. Xu, Q. Liu, and F. Kobashi, 2011: Dynamical role of mode water ventilation in decadal variability in the central subtropical gyre of the North Pacific. J. Climate, 24, 12121225, https://doi.org/10.1175/2010JCLI3896.1.

Xu, L., S.-P. Xie, Q. Liu, and F. Kobashi, 2011: Response of the North Pacific subtropical countercurrent and its variability to global warming. J. Oceanogr., 68, 127-137, https://doi.org/ 10.1007/s10872-011-0031-6.

,-- , and -2012 : Mode water ventilation and subtropical countercurrent over the North Pacific in CMIP5 simulations and future projections. J. Geophys. Res., 117, C12009, https:// doi.org/10.1029/2012JC008377.

_ _ _ J. L. McClean, Q. Liu, and H. Sasaki, 2014: Mesoscale eddy effects on the subduction of North Pacific mode waters. J. Geophys. Res., 119, 4867-4886, https://doi.org/10.1002/ 2014JC009861.
Yang, H., G. Lohmann, W. Wei, M. Dima, and J. Liu, 2016: Intensification and poleward shift of subtropical western boundary currents in a warming. J. Geophys. Res. Oceans, 121, 4928-4945, https://doi.org/10.1002/2015JC011513.

- B. Qiu, P. Chang, L. Wu, S. Wang, Z. Chen, and Y. Yang, 2018: Decadal variability of eddy characteristics and energetics in the Kuroshio Extension: Unstable versus stable states. J. Geophys. Res. Oceans, 123, 6653-6669, https:// doi.org/10.1029/2018JC014081.

— gyres detected in a warming climate. Geophys. Res. Lett., 47, e2019GL085868, https://doi.org/10.1029/2019GL085868.

Yang, J., X. Lin, S. Xie, Y. Zhang, Y. Kosaka, and Z. Li, 2020b: Synchronized tropical Pacific and extratropical variability during the past three decades. Nat. Climate Change, 10, 422427, https://doi.org/10.1038/s41558-020-0753-9.

Yin, J., 2005: A consistent poleward shift of the storm tracks in simulations of 21st century climate. Geophys. Res. Lett., 32, L18701, https://doi.org/10.1029/2005GL023684.

Yu, L., X. Jin, and H. Liu, 2018: Poleward shift in ventilation of the North Atlantic subtropical underwater. Geophys. Res. Lett., 45, 258-266, https://doi.org/10.1002/2017GL075772.

Zhang, C., X. Lin, C. Zhang, and Y. Guo, 2019: Subtropical countercurrent variations in cooling climates induced by freshwater forcing over the subarctic North Atlantic. Climate Dyn., 52, 2799-2812, https://doi.org/10.1007/s00382018-4293-1. 